Supplementary Information

\title{
Evaluating the protective effects of mitochondrial glutathione on cerebral ischemia/reperfusion injury via near-infrared fluorescence imaging
}

Xia Zhang, ${ }^{\dagger, \perp}$ Yan Huang,,${ }^{\dagger} \ddagger$ Xiaoyue Han,,${ }^{\dagger, \perp}$ Yue Wang,,${ }^{\dagger} \perp$ Liangwei Zhang, ${ }^{*}, \dagger$ and Lingxin Chen $*, \dagger, \dot{\dagger}, \S$

${ }^{\dagger}$ CAS Key Laboratory of Coastal Environmental Processes and Ecological Remediation, Research Centre for Coastal Environmental Engineering and Technology, Yantai Institute of Coastal Zone Research, Chinese Academy of Sciences, Yantai 264003, China

*School of Pharmacy, Binzhou Medical University, Yantai 264003, China

$\S$ Center for Ocean Mega-Science, Chinese Academy of Sciences, Qingdao 266071, China

$\perp$ University of Chinese Academy of Sciences, Beijing 100049, China

E-mail: liangweizhang@yic.ac.cn (L.Zhang); lxchen@yic.ac.cn (L.Chen)

\section{Contents:}

1. General Methods

2. Synthesis of the Compounds

3. Spectral properties of BCy-SeSe for GSH.

4. UV-vis absorption spectra and fluorescence spectra of BCy-SS towards GSH

5. Effect of $\mathrm{pH}$ Values

6. Photostability of BCy-SeSe and BCy-SS under the working conditions

7. Selectivity of BCy-SS towards GSH

8. MTT Assay for BCy-SeSe and BCy-SS

9. Time-course of GSH levels after $\mathrm{H}_{2} \mathrm{O}_{2}$ treated in HT-22 cells with BCy-SeSe

10. Imaging GSH and co-localization in living HT-22 cells with BCy-SS

11. Bright-field images of Figure 1 and other images of co-localization

12. Bright-field images of Figure 2, Figure 3 and Figure 4

13. Representative slides of TUNEL staining of lesion brain sections in Figure 6

14. The purities tests of BCy-SeSe and BCy-SS by HPLC

15. The solubility of the probes

16. ${ }^{1} \mathrm{H} \mathrm{NMR},{ }^{13} \mathrm{C}$ NMR and MS

17. Reference 


\section{General Methods}

Materials: The solution of the probes BCy-SeSe and BCy-SS $(1 \mathrm{mM}, 10 \mathrm{~mL})$ were prepared by dissolving in dimethyl sulfoxide (DMSO) and stored in darkness at $4{ }^{\circ} \mathrm{C}$, respectively. Unless indicated otherwise, all chemicals that used in synthesis were from commercial sources and of analytical reagent grade. All the reagents with the highest grade commercially available were obtained from J\&K Chemical Ltd (Shanghai, China), Energy Chemical (Shanghai, China) and Aladdin (USA). To monitor reaction process, the thin-layer chromatography (TLC) was often performed on silica gel plates. And silica gel P60 200-300 mesh and reversed phase silica gel C18 200-300 mesh were used for the furture purification of compounds. Ultrapure water was used for the preparation of all the teated solutions.Ultrapure water used in experiment throughout and purified from Wahaha water via a Millipore Milli-Q system (Millipore, Bedford, MA, USA). Hippocampal neuronal cell line (HT22), human astrocytoma cells (U87), human neuroblastoma cells (SH-SY5Y), human lung carcinoma cells (PC9), human hepatocellular carcinoma cell line (SMMC-7721), human normal liver cell line (HL-7702) and human embryonic kidney cells (HEK 293) were purchased from the Stem Cell Bank, Chinese Academy of Sciences (Shanghai, China). Dulbecco's Modified Eagle's Medium (DMEM) was brought from HyClone. Minimum Essential Medium (MEM) and Fetal Bovine Serum (FBS) were brought from gibco of Thermo Fisher Scientific. 3-(4,5-Dimethylthiazol-2-yl)-2,5-diphenyltetrazolium bromide (MTT) was purchased from Sigma-Aldrich. The following reagents were purchased from Thermo Fisher Scientific: JC-1, Minimum Essential Medium (MEM), Roswell Park Memorial Institute (RPMI) 1640 Medium and Fetal Bovine Serum (FBS). Annexin V/7-AAD Apoptosis Detection Kit was purchased from BD Biosciences.

Instruments: Absorption spectra were obtained on Lambda 35 UV-visible spectrophotometer (PerkinElmer). Fluorescence spectra were obtained by FluoroMax-4 Spectrofluorometer with a Xenon lamp and 1.0-cm quartz cells (HORIBA Scientific, France). 1H NMR and 13C NMR spectra were recorded on Bruker AVANCE IIITM 500 spectrometer. High-resolution mass spectra were analyzed on LCQ Fleet LC-MS System (Thermo Fisher Scientific). The $\mathrm{pH}$ measurements were constructed with a $\mathrm{pH}-3 \mathrm{c}$ digital $\mathrm{pH}$ meter with a combined glass-calomel electrode (Shanghai Lei Ci Device Works, Shanghai, China). The fluorescence images of cells were acquired on an Olympus Fluo View FV1000 confocal laser-scanning microscope with an objective lens (×60) (Japan). The samples of flow cytometry analysis were used BD Biosciences FACS Aria (USA). The fluorescence imaging in vivo were taken via IVIS Lumina XRMS Series III (USA, Perkinelmer).

Spectral analysis: All the photophysical characterization determinations were carried out at $37^{\circ} \mathrm{C}$ and the ultrapure water was used to prepare all aqueous solutions. The $1.0-\mathrm{cm}$ quartz cells were selected in the measurement of ultraviolet spectra and fluorescence spectra. 4-(2-hydroxyethyl)-1-piperazineethanesulfonic acid (HEPES, $10 \mathrm{mM}, \mathrm{pH}$ 7.4) was used to dilute all the solutions and purged with $\mathrm{N}_{2}$ for 10 min before use. The probe (DMSO, $1.0 \mathrm{mM}, 0.1 \mathrm{~mL}$ ) was diluted to $10.0 \mu \mathrm{M}$ with $10 \mathrm{mM}$ HEPES in $10.0 \mathrm{~mL}$ color comparison tube and then the analytes were added into the solution. The mixture was equilibrated for $2 \mathrm{~min}$ before measurement. The fluorescence intensity were measured at $\lambda_{\mathrm{ex} / \mathrm{em}}=654 / 675-860 \mathrm{~nm}$ and the maximum emission wavelength was $728 \mathrm{~nm}$.

Cytotoxicity assays: Biosecurity of probes were performed by 3-(4, 5)-dimethylthiahiazo (-z-y1)-3, 5- diphenytetrazoliumromide (MTT) assay. The HT22 cells were $\left(10^{6}\right.$ cells $\left./ \mathrm{mL}\right)$ were seeded into 96-well microtiter plates with DMEM culture medium supplemented with 10\% FBS and cultured 
under $95 \%$ humidified atmosphere with $5 \% \mathrm{CO}_{2}$ at $37{ }^{\circ} \mathrm{C}$ for $24 \mathrm{~h}$. And then different concentrations of BCy-SeSe and BCy-SS were added into each well from $0 \mu \mathrm{M}$ to $80 \mu \mathrm{M}$ and cultured in dark for $24 \mathrm{~h}$ respectively. MTT solution $(5.0 \mathrm{mg} / \mathrm{mL}, 20 \mu \mathrm{L}$, PBS) was then added to each well after washing wells by PBS. After $4 \mathrm{~h}$ of incubation, removing the remaining MTT and then adding DMSO to dissolve the formazan crystals. The absorbance of treated cells was compared with the absorbance of the controls, which cells were exposed only to the vehicle and were considered as $100 \%$ viability value. ${ }^{1}$ The absorbance was determined using a microplate reader (Tecan, Austria).

\section{Cell culture}

All the tested cells were purchased from Stem Cell Bank, Chinese Academy of Sciences. Using Dulbecco's Modified Eagle's Medium (DMEM) to incubate human astrocytoma cells (U87), Hippocampal neuronal cell line (HT-22), human hepatocellular carcinoma cell line (SMMC-7721) and human lung carcinoma cells (PC9); Minimum Essential Medium (MEM) for human embryonic kidney cells (HEK 293) and RPMI (Roswell Park Memorial Institute) 1640 Medium for human neuroblastoma cells (SH-SY5Y) and human normal liver cell line (HL-7702). All the cell culture mediums supplemented with 10\% Fetal Bovine Serum (FBS, gibco), and cultured the cells under 5\% $\mathrm{CO}_{2}$ humidified atmosphere at $37{ }^{\circ} \mathrm{C}$. All the cells were incubated with same culture conditions as described in experimental section before operating for the FCA. The operation of FCA of mitochondrial membrane potential and apoptosis were executed according to the specification of JC-1 and Annexin V/7-AAD.

\section{Incubation of cell ischemia/reperfusion models}

Glucose-serum-oxygen deprivation group was simultaneously treated with oxygen-free, serum-free and glucose-free medium for $2 \mathrm{~h}$. Glucose-serum-oxygen deprivation/reperfusion $20 \mathrm{~min}$ group was treated as glucose-serum-oxygen deprivation group and then cultured with normalized mediums and $\mathrm{O}_{2}$ concentration for another $20 \mathrm{~min}$. Glucose-serum-oxygen deprivation/reperfusion 90 min group was treated with oxygen-free, serum-free and glucose-free medium for $2 \mathrm{~h}$ and then cultured with normalized mediums and $\mathrm{O}_{2}$ concentration for another $90 \mathrm{~min}$. Different cell lines: All the cells in the experimental models were primitively cultured until stabilization under normal culture conditions. The groups of serum deprivation were cultured with serum-free culture mediums for $2 \mathrm{~h}$. To construe hypoxic conditions, the groups of oxygen deprivation were incubated under $0.1 \% \mathrm{O}_{2}$ concentration for $2 \mathrm{~h}$ via AnaeroPack and other culture conditions as normal. The cell culture mediums of the glucose deprivation groups were supplied without glucose and other conditions as normal and incubated for $2 \mathrm{~h}$. Oxygen-serum-glucose deprivation groups were simultaneously treated with oxygen-serum-glucose deprivation for $2 \mathrm{~h}$. Oxygen-serum-glucose deprivation/reperfusion groups were simultaneously treated with oxygen-serum-glucose deprivation for $2 \mathrm{~h}$ and then cultured with normalized mediums and $\mathrm{O}_{2}$ concentration for another $20 \mathrm{~min}$.

Endogenous glutathione (GSH) changes during different cases of cell I/R process in different cell lines. Group a were control when the cells were cultured with standard cell culture medium (containing $4.5 \mathrm{~g} / \mathrm{L}$ glucose, 10\% Fetal Bovine Serum) under normal conditions (95\% humidified atmosphere, $37^{\circ} \mathrm{C}$ ). Group b were treated with serum-free cell culture medium and cultured under normal conditions for $2 \mathrm{~h}$ as serum deprivation group. Group c were treated with standard cell culture medium and cultured under $0.1 \% \mathrm{O}_{2}$ atmosphere at $37{ }^{\circ} \mathrm{C}$ for $2 \mathrm{~h}$ as oxygen deprivation group. Group d were treated with glucose-free cell culture medium and cultured under normal conditions for $2 \mathrm{~h}$ as glucose deprivation group. Group e were cultured with glucose-free and serum-free cell culture medium under $0.1 \% \mathrm{O}_{2}$ atmosphere for $2 \mathrm{~h}$ as glucose-serum-oxygen 
deprivation group. Group $\mathrm{f}$ were cultured with the same treatment as group $\mathrm{e}$ for glucose-serum-oxygen deprivation $2 \mathrm{~h}$ and then recovered the standard cell culture medium (containing $4.5 \mathrm{~g} / \mathrm{L}$ glucose, 10\% Fetal Bovine Serum) under normal culture conditions for another $20 \mathrm{~min}$ as glucose-serum-oxygen deprivation/reperfusion group. All the cells were washed with PBS for three times and then incubated with BCy-SeSe $(10 \mu \mathrm{M})$ for 2 min before imaging.

\section{Apoptosis experiments and flow cytometry analysis}

All the tested cells were cultured in 6-well plates $\left(2.0 \times 10^{5}\right.$ cells/well $)$, and then treated with probes as described in the paper. Before harvest, washing and suspending the cells with PBS and analyzed by flow cytometry. The detection of fluorescence on flow cytometry channel was chosen as PerCP-cy 5.5. The samples were detected by BD Biosciences FACS Aria, and the data were analyzed by Software of Flowing.

Apoptosis Experiments. Hippocampal neuronal cells (HT-22) were inoculated into six well plates $\left(2.0 \times 10^{5}\right.$ cells/well) and cultured according to the description in Figures. Washing the cells with the PBS and digested them into centrifuge tubes after harvest. And then suspended the cells into $100 \mu \mathrm{L}$ binding buffer and added $5 \mu \mathrm{L}$ 7-AAD and Annexin V-FITC into the above solution, respectively. The cells were kept in dark place at $25^{\circ} \mathrm{C}, 15 \mathrm{~min}$. Before analyzed by flow cytometry, suspended cells with $400 \mu \mathrm{L}$ binding buffer.

Flow cytometry analysis. Incubating the cells according to the description in the experiment section, washed and suspended the cells with PBS after experimental incubation. The detection of fluorescence on flow cytometry channel was chosen as PerCP-cy 5.5. The samples were detected by BD Biosciences FACS Aria, and the data were analyzed by Software of Flowing.

\section{Western blot}

The cells or tissues were operated according to the description in text and washed with cold PBS for three times. The extraction of protein was operated via using $200 \mu \mathrm{L}$ mixed solution of RIPA lysis buffer and PMSF (v/v, 100:1) to lyse cells for $30 \mathrm{~min}$ and adding $200 \mu \mathrm{L} / 10 \mathrm{mg}$ mixed solution to lyse tissues. Subsequently, the samples were scraped and centrifuged (15min, $12500 \mathrm{rpm}$ ) at $4{ }^{\circ} \mathrm{C}$. The supernatant of the samples were separated and the protein concentrations were determined by BCA kit (Biogot, China). After denatured, equal amounts of protein were electrophoresed on 6-12\% SDS-polyacrylamide gels (Bio-Rad, USA) and transferred to PVDF membranes (Millipore, Germany). The electrophoretic conditions and transfer conditions were ultimately optimized for $80 \mathrm{~V}, 100 \mathrm{~min}$ and $200 \mathrm{~mA}, 2 \mathrm{~h}$, respectively. Subsequently, the membranes were blocked with $7 \%$ milk and blotted with primary antibodies overnight at $4{ }^{\circ} \mathrm{C}$. A horseradish peroxidase (HRP)-conjugated secondary antibody (Cell Signaling Technology, USA) was used to mirror the quantity of proteins with $2 \mathrm{~h}$ incubation and signals were detected with an enhanced chemiluminescence (ECL) detection system.

\section{Fluorescence confocal microscopic imaging of cells}

The fluorescence imagings of all cell lines were achieved via confocal laser-scanning microscope (Olympus FluoView FV1000, Japan) with an objective lens $(\times 60)$, which equipped with $635 \mathrm{~nm}$ laser for probes and collected emission from $700 \mathrm{~nm}$ to $800 \mathrm{~nm}$. The other commercially available fluorescence dyes were operated according to the instructions. The analysis of the co-localization parameters were acquired by Image-Pro Plus software. By purchasing AnaeroPack (Japan, Mitsubishi Gas Chemical Campany) for constructing hypoxic conditions, we incubated cells under $0.1 \% \mathrm{O}_{2}$ concentration. $^{2}$ Before imaging, above cells were washed for three times with PBS after operation and then incubated with BCy-SeSe or BCy-SS $(10 \mu \mathrm{M})$ at $37{ }^{\circ} \mathrm{C}$ for $2 \mathrm{~min}$. The 
fluorescence images displayed represent emission collected windows: $\lambda_{\mathrm{em}}=700-800 \mathrm{~nm}, \lambda_{\mathrm{ex}}=635$ nm.

\section{Construction of middle cerebral intery occlusion models in mice}

All the male BALB/c mice, purchased from Binzhou Medical University, were fasted overnight prepared for focal cerebral ischaemia. We constructed six groups of mice MCAO models. The mice were anesthetized by chloral hydrate via i.p. injection before operation. For focal cerebral ischaemia, MCAO models were induced by occluding the left internal carotid artery of mice. ${ }^{3} \mathrm{We}$ used commercially available MCAO monofilaments to establish the MCAO models. Concretely, the MCAO monofilaments approximately inserted $10 \mathrm{~mm}$ into the left internal carotid to occlude the origin of the MCA. Subsequently, reperfusion was achieved by removing monofilament after 2 hours of ischemia. The body temperature of surgery mice were maintained at $37{ }^{\circ} \mathrm{C}$ assisted with a heat lamp during surgery and earlier stage of reperfusion. To build different degree of cerebral infarction MCAO mice models, given different time of reperfusion at 0 hours, 6 hours, 12 hours, and 24 hours, after different time of ischemia. The mice were operated as experimental group except occluded carotid artery set as control group. Besides, in order to evaluate GSH efficacy in the MCAO models of mice, we added L-buthionine sulphoximine (BSO, the specific inhibitor of $\gamma$-glutamylcysteine synthetase) group and GSH-ester group. They were pretreated with BSO or GSH-ester and then underwent $2 \mathrm{~h}$ MCAO followed by $24 \mathrm{~h}$ reperfusion. BSO was injected into mice via intraperitoneal injection with dose of $2.5 \mathrm{mmol} / \mathrm{kg}$ before operation twice daily and interval of $12 \mathrm{~h}$. GSH-ester was injected into mice via intraperitoneal injection with dose of $3 \mathrm{mmol} / \mathrm{kg}$ before operation twice daily and interval of $12 \mathrm{~h}$. Besides, BSO was delivered into mice in 5\% dimethyl sulfoxide, which could increase BSO uptake by brain. ${ }^{4}$ The sham group underwent same operation without any practical occlusion and the control experiments mice were given equivalent amounts of saline solution.

\section{Fluorescence imaging in vivo}

Fluorescence imaging in vivo were taken via IVIS Lumina XRMS Series III (USA, Perkinelmer). The MCAO mice, operated as described in paper, were anesthetized by chloral hydrate $(400 \mathrm{mg} / \mathrm{kg})$ with i.p. injection. Mice were intracranially injected with BCy-SeSe $(10 \mu \mathrm{M}, 100 \mu \mathrm{L}$, $\mathrm{DMSO} /$ saline, 1: $99, \mathrm{v} / \mathrm{v}$ ) and keeping them in the atmosphere of $2 \%$ isoflurane during imaging. We employed BCy-SeSe to examine the changes of GSH in MCAO mice model of acute $\mathrm{I} / \mathrm{R}$. The wavelengths of excitation and emission were set as mentioned earlier about probe.

Fluorescence imaging of GSH levels in cerebral artery occlusion mice models of adult and aging mice. Group a as sham group, the mice give $0 \mathrm{~h}$ ischemia and $0 \mathrm{~h}$ reperfusion as control. The mice in group $\mathrm{b}$ were operated with MCAO for $2 \mathrm{~h}$ and reperfusion $0 \mathrm{~h}$ as Ischemia group. The mice in group c were operated with MCAO for $2 \mathrm{~h}$ and reperfusion $6 \mathrm{~h}$ as Ischemia-reperfusion $6 \mathrm{~h}$ group. The mice in group $\mathrm{d}$ were operated with MCAO for $2 \mathrm{~h}$ and reperfusion $12 \mathrm{~h}$ as Ischemia-reperfusion $12 \mathrm{~h}$ group. The mice in group e were operated with MCAO for $2 \mathrm{~h}$ and reperfusion $24 \mathrm{~h}$ as Ischemia-reperfusion $24 \mathrm{~h}$ group.

\section{Synthesis of the Compounds}

\section{Synthesis and Characterization of fluorophore BCy-Keto}

The mixture of 1,1,2-Trimethyl-1H-benz[e]indole $(105.0 \mathrm{mg}, 0.5 \mathrm{mmol})$ and iodoethane (78.0 $\mathrm{mg}, 0.5 \mathrm{mmol}$ ) in acetonitrile was refluxed for $12 \mathrm{~h}$ to give the compound 4 (Scheme S1) after the filtration, yield $84 \%$. Compound $4(95.2 \mathrm{mg}, 0.4 \mathrm{mmol})$ reacted with 4-Hydroxyisophthalaldehyde $(30.0 \mathrm{mg}, 0.2 \mathrm{mmol})$ in the mixed solvent of n-butyl alcohol and toluene at a proper ratio $(7: 3, \mathrm{v} / \mathrm{v})$ to 
give compound 2 via more than 3 hours' refluxed. EtOAc/ $\mathrm{CH}_{3} \mathrm{OH}(3: 1, \mathrm{v} / \mathrm{v})$ was selected as the eluent to purify the green crude solid via the silica gel column chromatography (200 - $300 \mathrm{mesh}$ ), 76\%. ${ }^{1} \mathrm{H}$ NMR (500MHz, DMSO-D 6 ) $\delta(\mathrm{ppm}): 8.53-8.50(\mathrm{~d}, 1 \mathrm{H}), 8.45-8.43(\mathrm{~d}, 1 \mathrm{H}), 8.32-8.12(\mathrm{~m}$, $6 \mathrm{H}), 7.86-7.82(\mathrm{~m}, 3 \mathrm{H}), 7.60-7.57(\mathrm{~d}, 1 \mathrm{H}), 7.45-7.42(\mathrm{~m}, 1 \mathrm{H}), 7.25-7.14(\mathrm{~m}, 4 \mathrm{H}), 6.91-6.89(\mathrm{~d}, 1 \mathrm{H})$, 6.09-6.07 (d, 1H), 4.87-4.83 (q, 2H), 3.37-3.33 (q, 2H), $2.04(\mathrm{~s}, 6 \mathrm{H}), 1.58(\mathrm{~s}, 3 \mathrm{H}), 1.54-1.51(\mathrm{t}, 3 \mathrm{H})$, $1.29(\mathrm{~s}, 3 \mathrm{H}), 1.19-1.16(\mathrm{t}, 3 \mathrm{H}) .{ }^{13} \mathrm{C}$ NMR $\left(125 \mathrm{MHz}, \mathrm{DMSO}_{6}\right) \delta(\mathrm{ppm}): 182.14,162.76,159.33$, $153.24,144.89,138.67,138.60,133.89,133.56,131.53,130.73,130.51,130.13,129.85,129.46$, $129.17,128.89,127.61,127.54,127.30,127.00,124.85,123.55,121.89,121.38,121.16,119.53$, $116.28,113.52,110.55,109.65,107.67,55.42,54.19,54.06,42.62,37.80,26.12,21.45,14.86$, 14.36. LC-MS (ESI $\left.{ }^{+}\right): \mathrm{m} / \mathrm{z} \mathrm{C}_{42} \mathrm{H}_{41} \mathrm{~N}_{2} \mathrm{O}^{+}$calcd. 589.3213, found $\left[\mathrm{M}^{+}\right]$589.3219.

\section{Synthesis and Characterization of $\mathrm{BCy}-\mathrm{SeSe}$ and $\mathrm{BCy}-\mathrm{SS}$}

Triphosgene ( $89.1 \mathrm{mg}, 0.3 \mathrm{mmol})$ and BCy-Keto $(58.9 \mathrm{mg}, 0.1 \mathrm{mmol})$ were dissolved in $60 \mathrm{~mL}$ anhydrous $\mathrm{CH}_{2} \mathrm{Cl}_{2}$ solution under $0{ }^{\circ} \mathrm{C}$ and $\mathrm{Ar}$ atmosphere, and then $1 \mathrm{~mL}$-ethyldiisopropylamine (DIPEA) was added into the above solution. After 3 hours of stir, solvent was removed under vacuum condition and another anhydrous $\mathrm{CH}_{2} \mathrm{Cl}_{2}(60 \mathrm{~mL})$, 4-dimethylaminopyridine (16 $\left.\mathrm{mg}\right)$, DIPEA $(1 \mathrm{~mL})$ were added into the obtained residue. Bis (2-hydroxyethyl) diselenide (49.6 mg, 0.2 mmol) or 2, 2'-dithiodiethanol $(30.0 \mathrm{mg}, 0.2 \mathrm{mmol})$ was instilled into the mixture and reacted for 16 hours under ambient temperature. ${ }^{1}$ The crude product was collected through washing the solution with $\mathrm{H}_{2} \mathrm{O}(80 \mathrm{~mL})$ for three times followed by concentrated the organic layer. The silica chromatography (200-300 mush) was used to purify the product with dichloromethane and methanol as eluents.

The yield of BCy-SeSe was 53\%. ${ }^{1} \mathrm{H}$ NMR $\left(500 \mathrm{MHz}, \mathrm{DMSO}-\mathrm{D}_{6}\right) \delta(\mathrm{ppm}): 8.62-8.59(\mathrm{~m}, 1 \mathrm{H})$, 8.48-8.17 (m, 5H), 8.06-7.68 (m, 6H), 7.47-7.45 (t, 1H), 7.28-7.25 (t, 2H), 7.15-7.13 (d, 1H), 6.85-6.83 (d, 1H), 6.80-6.79 (d, 1H), $5.65(\mathrm{~s}, 1 \mathrm{H}), 4.82-4.79(\mathrm{~m}, 2 \mathrm{H}), 4.69-4.65(\mathrm{~m}, 4 \mathrm{H}), 4.34(\mathrm{~s}$, $1 \mathrm{H}), 3.48-3.33(\mathrm{~m}, 2 \mathrm{H}), 1.59(\mathrm{~s}, 12 \mathrm{H}), 1.35-1.27(\mathrm{t}, 4 \mathrm{H}), 1.20-1.17(\mathrm{t}, 6 \mathrm{H}) .{ }^{13} \mathrm{C}$ NMR $(125 \mathrm{MHz}$, DMSO-D $\left._{6}\right) \delta(\mathrm{ppm}): 179.72,173.27,159.33,144.76,138.67,138.61,138.47,138.22,137.71$, $136.83,133.49,133.10,132.83,131.56,131.26,130.38,130.03,129.74,129.38,129.18,129.06$, $128.85,127.58,127.45,127.37,127.19,126.96,124.80,123.24,121.89,121.22,119.63,116.17$, $113.09,110.38,107.66,65.59,54.84,54.06,42.56,26.72,26.59,25.95,14.52,13.95$. LC-MS $\left(\mathrm{ESI}^{+}\right): \mathrm{m} / \mathrm{z} \mathrm{C}_{47} \mathrm{H}_{50} \mathrm{~N}_{2} \mathrm{O}_{4} \mathrm{Se}_{2}{ }^{2+}$ calcd. 433.1045, found $\left[\mathrm{M}^{2+}\right] 433.1029$.

The yield of BCy-SS was 74\%. ${ }^{1} \mathrm{H}$ NMR $\left(500 \mathrm{MHz}, \mathrm{DMSO}-\mathrm{D}_{6}\right) \delta(\mathrm{ppm}): 8.76-8.58(\mathrm{~m}, 3 \mathrm{H})$, 8.44-8.27 (m, 3H), 8.14-7.80 (m, 5H), 7.53-7.47 (m, 2H), 7.34-7.17 (m, 3H), 6.88-6.87 (m, 2H), 5.74 $(\mathrm{s}, 1 \mathrm{H}), 4.91-4.90(\mathrm{t}, 2 \mathrm{H}), 4.74-4.70(\mathrm{q}, 2 \mathrm{H}), 4.24(\mathrm{~s}, 1 \mathrm{H}), 3.48-3.37(\mathrm{~m}, 2 \mathrm{H}), 3.27-3.25(\mathrm{~m}, 2 \mathrm{H})$, 2.87-2.74 (m, 4H), 2.09-2.08 (s, 12H), 1.64-1.61 (t, 6H). ${ }^{13} \mathrm{C} \mathrm{NMR} \mathrm{(125} \mathrm{MHz,} \mathrm{DMSO-D} 6$ ) $\delta(p p m):$ $182.34,181.97,159.69,153.51,149.75,149.53,149.31,145.12,138.96,138.56,137.03,136.83$, $136.63,133.85,131.95,130.41,129.76,129.58,129.46,129.18,127.53,127.31,125.16,124.51$, $124.31,124.11,122.25,121.62,119.95,116.47,113.49,110.75,107.98,65.90,55.35,54.42,54.22$, 42.94, 38.03, 27.20, 27.09, 26.32, 14.93, 14.42. LC-MS $\left(\mathrm{ESI}^{+}\right): \mathrm{m} / \mathrm{z} \mathrm{C} \mathrm{C}_{47} \mathrm{H}_{50} \mathrm{~N}_{2} \mathrm{O}_{4} \mathrm{~S}_{2}{ }^{2+}$ calcd. 385.1600 , found $\left[\mathrm{M}^{2+}\right] 385.1601$. 


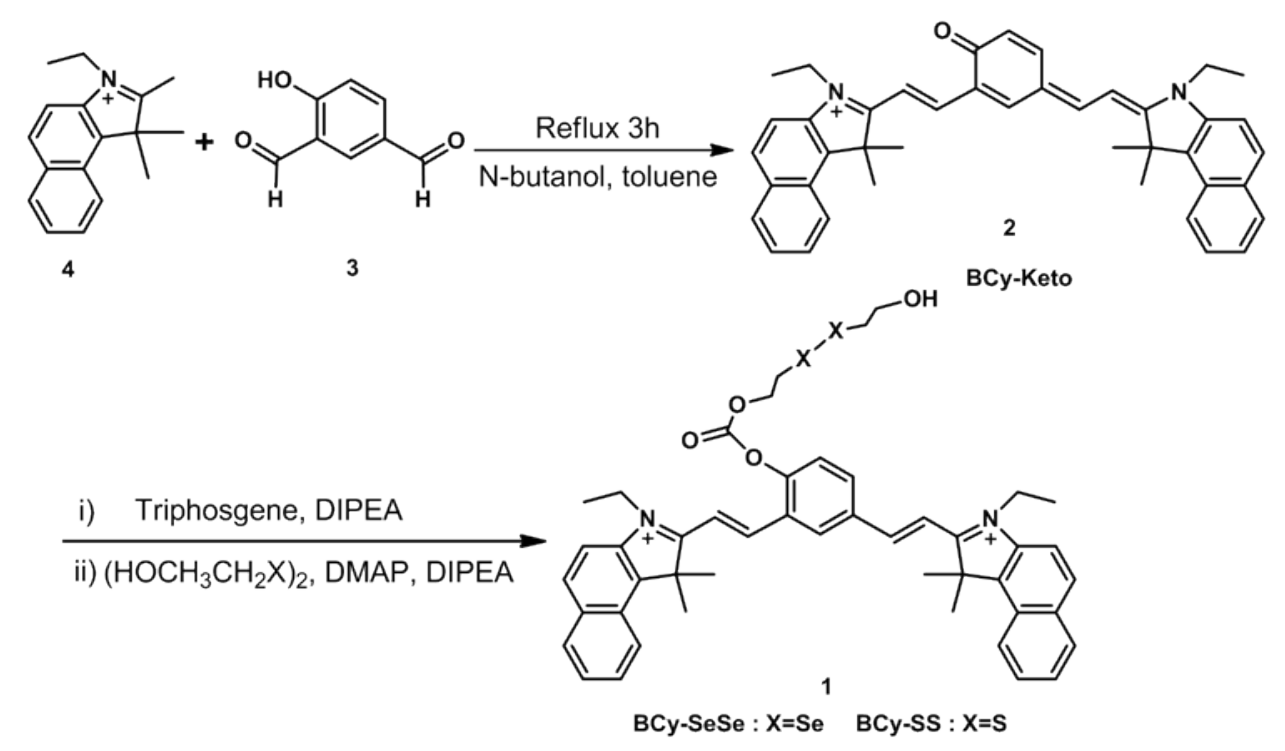

Scheme S1. Synthetic routes of BCy-SeSe and BCy-SS.

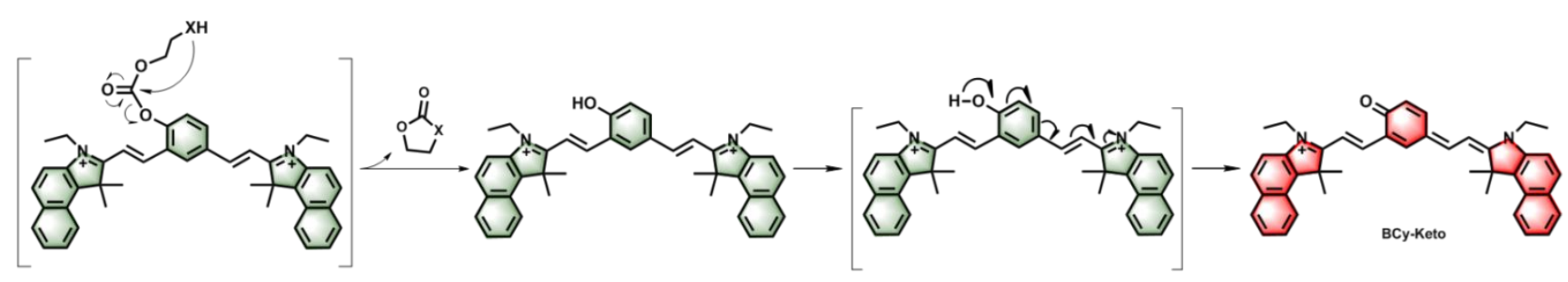

Scheme S2. The proposed detail mechanism during probes responding GSH

\section{Spectral properties of BCy-SeSe for GSH.}
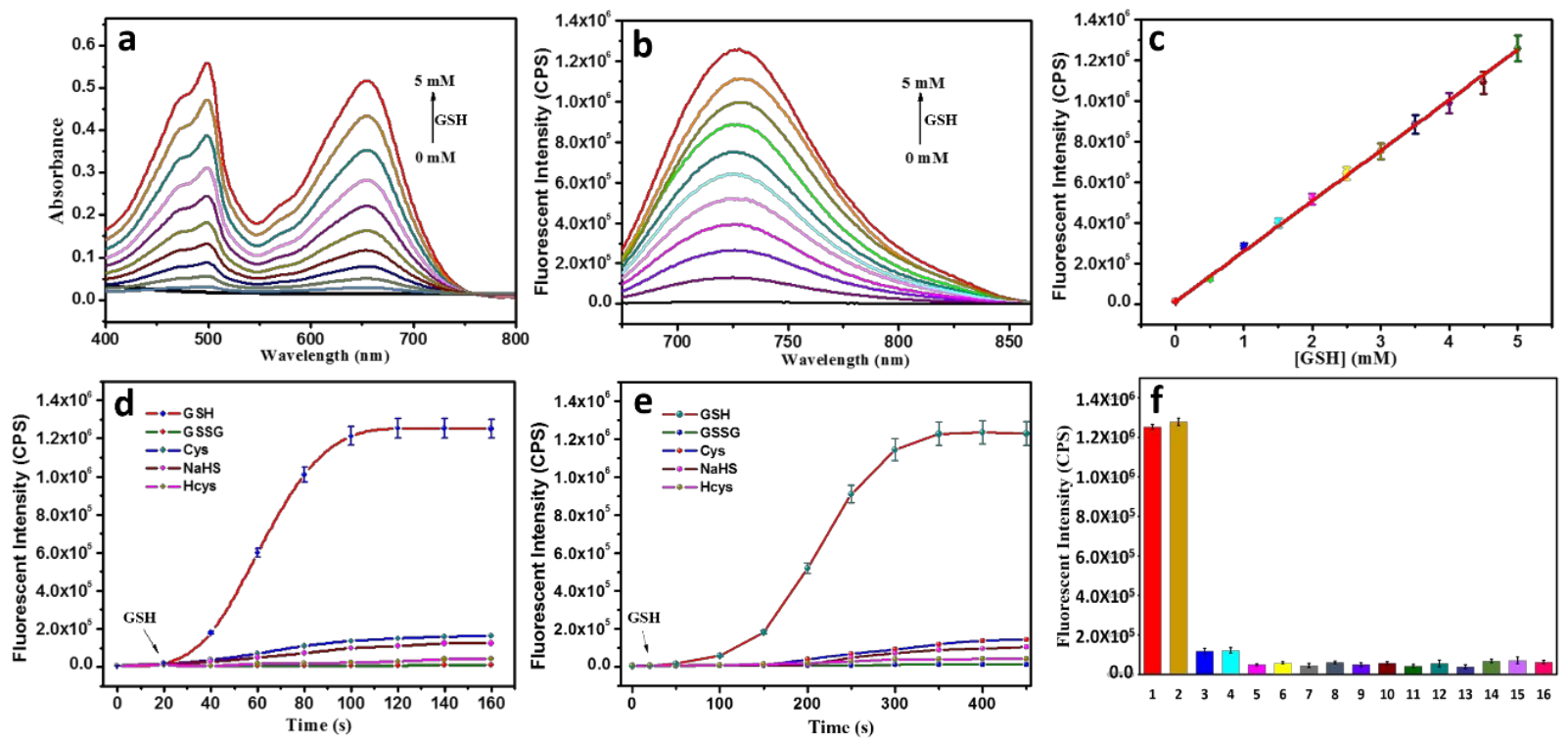

Figure S1. Spectral properties and selectivity of BCy-SeSe for GSH. (a) UV-vis absorption spectra of BCy-SeSe $(10 \mu \mathrm{M})$ incubated with $0-5 \mathrm{mM}$ GSH for $2 \mathrm{~min}$ at $37{ }^{\circ} \mathrm{C}$ under simulated biological environment. (b) Fluorescence spectra $\left(\lambda_{\mathrm{ex}}=654 \mathrm{~nm}\right)$ of BCy-SeSe $(10 \mu \mathrm{M})$ incubated with increasing GSH (0-5 mM). Each spectrum was recorded at 2 min. (c) The linear relationship about 
fluorescence intensity $(728 \mathrm{~nm})$ as function of GSH concentration. (d) BCy-SeSe (e) BCy-SS Time-dependent fluorescence intensity of probes $(10 \mu \mathrm{M})$ in the presence of GSH $(5 \mathrm{mM})$, GSSG $(100 \mu \mathrm{M})$, Cys $(100 \mu \mathrm{M})$, NaHS $(100 \mu \mathrm{M})$ and Hcy $(10 \mu \mathrm{M})$. (f) Fluorescence intensity of BCy-SeSe $(10 \mu \mathrm{M})$ upon adding various biological reactive species. (1) $5 \mathrm{mM} \mathrm{GSH}$; (2) Mixed solution of all involved interferents; (3) $100 \mu \mathrm{M}$ Cys; (4) $100 \mu \mathrm{M}$ NaHS; (5) $100 \mu \mathrm{M}$ GSSG; (6) $10 \mu \mathrm{M} \mathrm{Hcy;} \mathrm{(7)} 10$ $\mu \mathrm{M}$ Cystine; (8) $10 \mu \mathrm{M}$ Cys-SSH; (9) $10 \mu \mathrm{M}$ Selenocysteine; (10) $10 \mu \mathrm{M}$ N-acetyl-L-cysteine; (11) $10 \mu \mathrm{M}$ Scorbic acid; (12) $10 \mu \mathrm{M}$ L-cysteine methyl ester; (13) $10 \mu \mathrm{M}$ Lipoic acid; (14) $10 \mu \mathrm{M}$ SO42-; (15) $10 \mu \mathrm{M}$ HSO3-; (16) $10 \mu \mathrm{M} \mathrm{Na} 2 \mathrm{~S} 4$.

\section{UV-vis absorption spectra and fluorescence spectra of BCy-SS towards GSH}
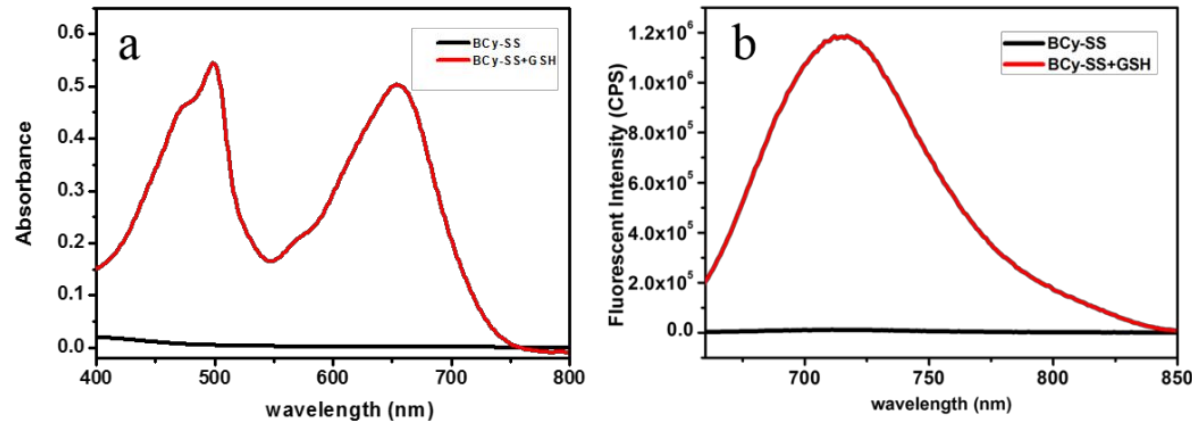

Figure S2. (a) UV-vis absorption spectra of BCy-SS $(10 \mu \mathrm{M})$ incubated with and without 5 mmol GSH for $5 \mathrm{~min}$ at $37^{\circ} \mathrm{C}$ in HEPES (pH 7.4, $10 \mathrm{mM}$ ) under simulated biological environment. (b) Fluorescence spectra $\left(\lambda_{\mathrm{ex}}=654 \mathrm{~nm}\right)$ of BCy-SS $(10 \mu \mathrm{M})$ incubated with $5 \mathrm{mM} \mathrm{GSH}$ and recorded at $5 \mathrm{~min}$.

\section{Effect of pH Values}

To verify the feasibility of BCy-SeSe and BCy-SS as GSH selective probes, we evaluated the influence of $\mathrm{pH}$ values for the fluorescence intensity of probes $(10 \mu \mathrm{M})$ in HEPES buffer $(10 \mathrm{mM}$, $0.5 \%$ DMSO, $0.4 \%$ Tween 80 ), respectively. ${ }^{5}$ The preparation of different $\mathrm{pH}$ buffer solutions is determined by titration. ${ }^{6}$ As shown in Fig. S1, BCy-SeSe and BCy-SS $(10 \mu \mathrm{M})$ displayed stable feeble fluorescence intensity during $\mathrm{pH} 4.0$ to 9.0 in buffer solution. However, the fluorophore BCy-Keto $(10 \mu \mathrm{M})$ showed prominent changes of fluorescence intensity when the $\mathrm{pH}$ values changed from 4.0 to 6.0 . The $\mathrm{pH}$ values varied from 6.0 to 7.0 , the fluorescence intensity gradually tend to saturation. The fluorescence intensity of fluorophore BCy-Keto keep stable from 7.0 to 9.0. These results indicated that the probes could be used to detect GSH without interference of $\mathrm{pH}$ under physiological conditions. 


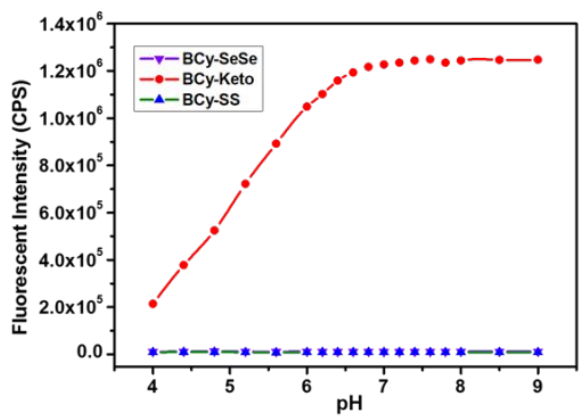

Figure S3. Effects of $\mathrm{pH}$ values on the fluorescence intensity of BCy-SeSe, BCy-SS and BCy-Keto $(10 \mu \mathrm{M})$ in HEPES buffer $(10 \mathrm{mM}, 0.4 \%$ Tween $80,0.5 \%$ DMSO $)$ at $37^{\circ} \mathrm{C}$ for $15 \mathrm{~min}$, respectively. $\left(\lambda_{\mathrm{ex}}=654 \mathrm{~nm}, \lambda_{\mathrm{em}}=728 \mathrm{~nm}\right) \mathrm{pH}$ values: $4.0,4.4,4.8,5.2,5.6,6.0,6.2,6.4,6.6,6.8,7.0,7.2,7.4,7.6$, $7.8,8.0,8.5,9.0$.

\section{Photostability of $\mathrm{BCy}-\mathrm{SeSe}$ and $\mathrm{BCy}-\mathrm{SS}$ under the working conditions}

In order to test the photostability of our probes in solution under the working conditions, we performed the photostability experiments. ${ }^{7}$ The solution of the probes BCy-SeSe and BCy-SS (10 $\mu \mathrm{M})$ were prepared in phosphate buffer saline (PBS, $10 \mathrm{mM}, \mathrm{pH} 7.4)$ and serum solution (10\% fetal bovine serum (FBS) in $10 \mathrm{mM}$ HEPES, pH 7.4), respectively. At the time point of 2.5 hours, adding the GSH $(5 \mathrm{mM})$ and tested the fluorescence intensity every 0.5 hour with irradiation by a $150 \mathrm{~W}$ iodine-tungsten lamp during $7 \mathrm{~h},{ }^{8} \lambda_{\mathrm{ex}}=654 \mathrm{~nm}, \lambda_{\mathrm{em}}=728 \mathrm{~nm}$. The fluorescence intensities of $\mathrm{BCy}-\mathrm{SeSe}$ and BCy-SS at different time points were shown in Figure S4. And the fluorescence intensities were hardly affected under different physiological conditions, which indicated that $\mathrm{BCy}-\mathrm{SeSe}$ and BCy-SS were stable under physiological conditions.
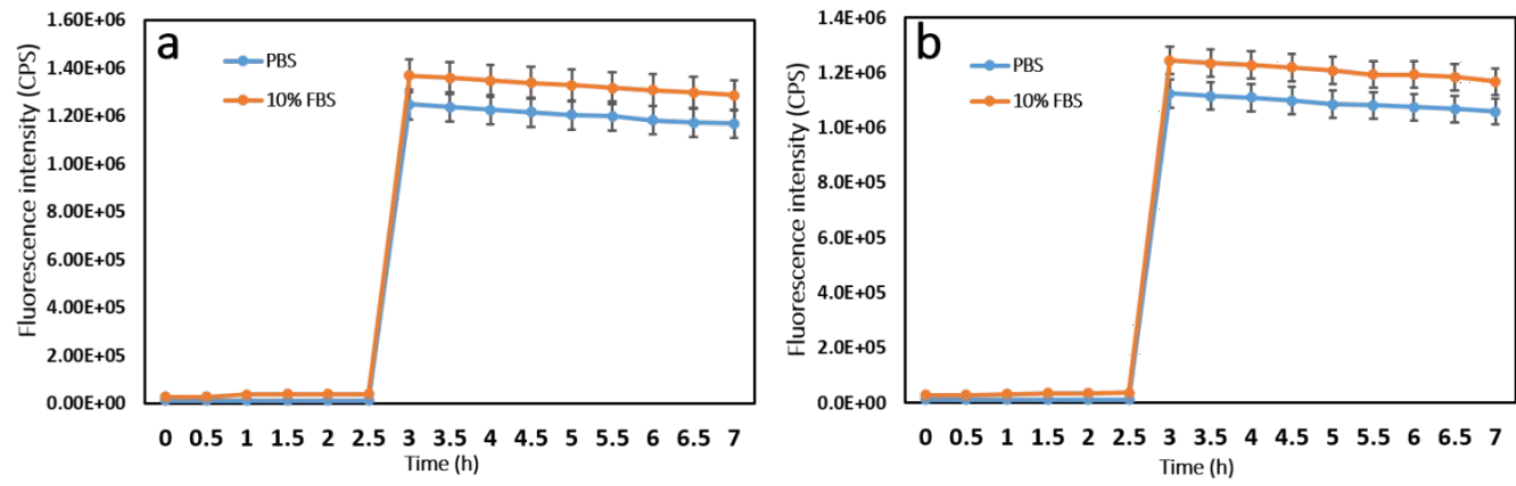

Figure S4. Fluorescence intensity of BCy-SeSe (a) and BCy-SS (b) for the photostability tests in the PBS or $10 \%$ FBS solutions. The fluorescence intensities were teated at different time points $(0 \mathrm{~h}, 0.5$ h, 1.0 h, 1.5 h, 2.0 h, 2.5 h, 3.0 h, 3.5 h, 4.0 h, 4.5 h, 5.0 h, 5.5 h, 6.0 h, 6.5 h, 7.0 h) under PBS (10 $\mathrm{mM}, \mathrm{pH} 7.4$ ), and serum solution (10\% fetal bovine serum (FBS) in $10 \mathrm{mM}$ HEPES, pH 7.4), respectively. $\lambda_{\mathrm{ex}}=654 \mathrm{~nm}, \lambda_{\mathrm{em}}=728 \mathrm{~nm}$.

\section{Selectivity of BCy-SS towards GSH}

To demonstrate that BCy-SS could well specifically monitor GSH in biological systems, we tested the significant parameter selectivity. The each fluorescence intensity of probe BCy-SS was 
evaluated upon addition with various biological reactive species while the maximum emission wavelength was $728 \mathrm{~nm}$ (excitation at $654 \mathrm{~nm}$ ) and the tested time at $6 \mathrm{~min}$.

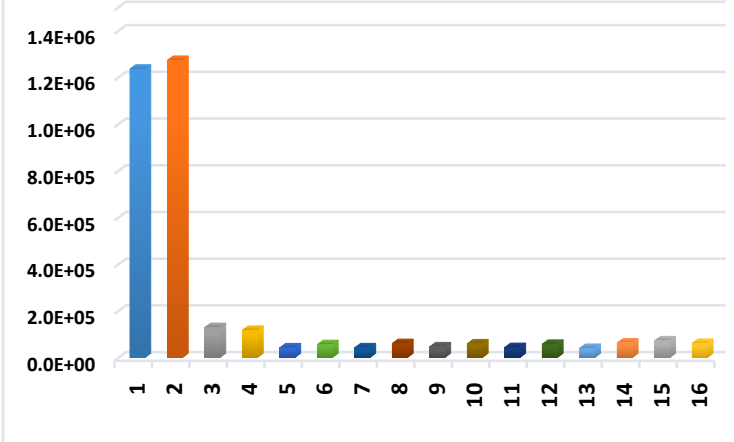

Figure S5. Fluorescence response of BCy-SS $(10 \mu \mathrm{M})$ upon addition with various biological reactive species. $\lambda_{\mathrm{ex}}=654 \mathrm{~nm}, \lambda_{\mathrm{em}}=728 \mathrm{~nm}$. (1) $5 \mathrm{mM} \mathrm{GSH}$; (2) Mixed solution of all involved interferents; (3) $100 \mu \mathrm{M}$ Cys; (4) $100 \mu \mathrm{M}$ NaHS; (5) $100 \mu \mathrm{M}$ GSSG; (6) $10 \mu \mathrm{M}$ Hcy; (7) $10 \mu \mathrm{M}$ Cystine; (8) 10 $\mu \mathrm{M}$ Cys-SSH; (9) $10 \mu \mathrm{M}$ Selenocysteine; (10) $10 \mu \mathrm{M}$ N-acetyl-L-cysteine; (11) $10 \mu \mathrm{M}$ Scorbic acid; (12) $10 \mu \mathrm{M}$ L-cysteine methyl ester; (13) $10 \mu \mathrm{M}$ Lipoic acid; (14) $10 \mu \mathrm{M} \mathrm{SO}_{4}^{2-}$; (15) $10 \mu \mathrm{M} \mathrm{HSO}_{3}^{- \text {; }}$ (16) $10 \mu \mathrm{M} \mathrm{Na}_{2} \mathrm{~S}_{4}$.

\section{MTT Assay for $\mathrm{BCy}-\mathrm{SeSe}$ and $\mathrm{BCy}-\mathrm{SS}$}
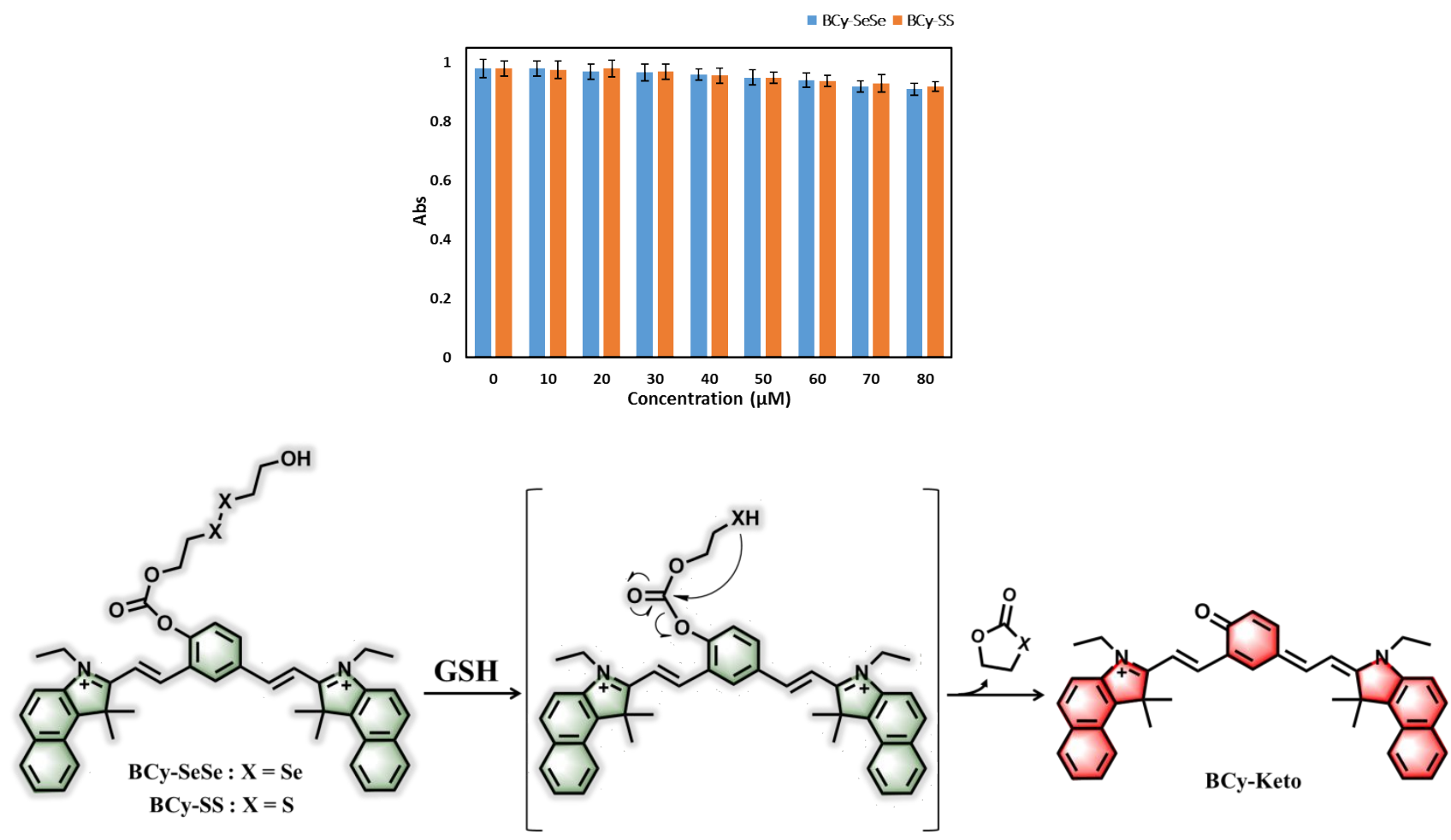

Figure S6. The cytotoxicity of HT-22 cells treated with different concentration of BCy-SeSe and BCy-SS $(0,10,20,30,40,50,60,70,80 \mu \mathrm{M})$ over $24 \mathrm{~h}$, respectively. The experiment was repeated three times and the data are shown as mean $( \pm$ S.D.). 


\section{Time-course of GSH levels after $\mathrm{H}_{2} \mathrm{O}_{2}$ treated in $\mathrm{HT}-22$ cells with $\mathrm{BCy}-\mathrm{SeSe}$}

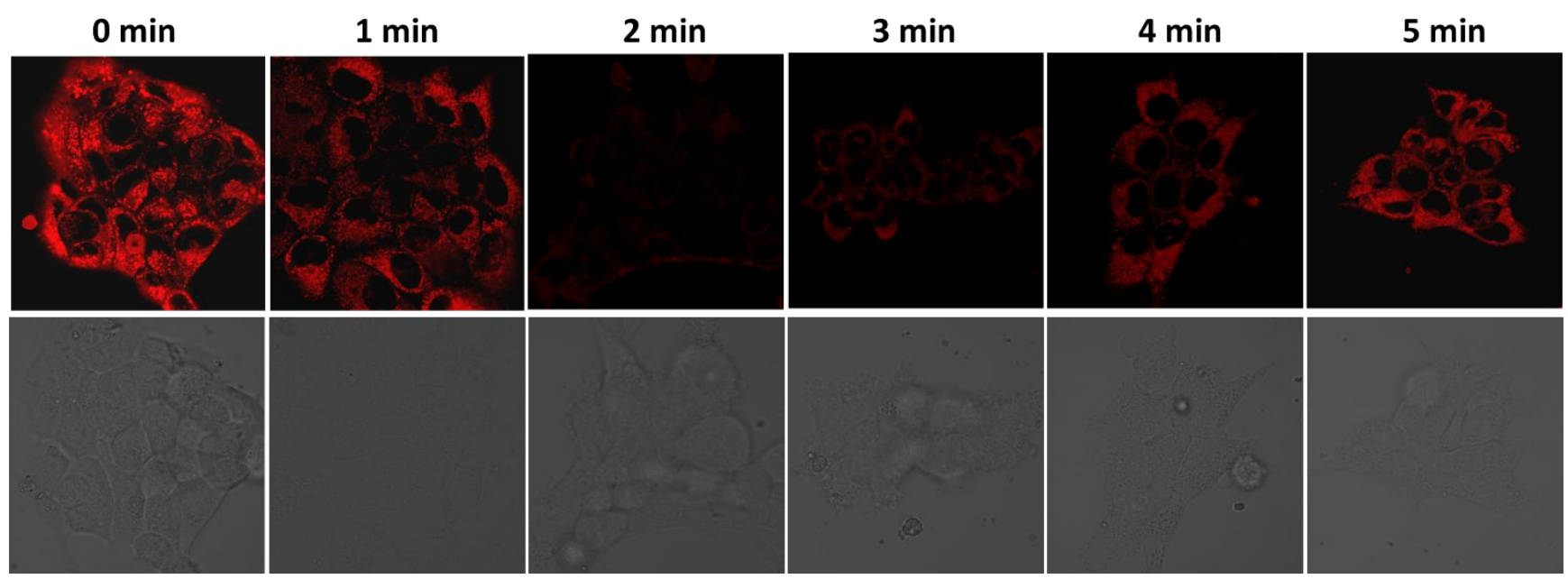

Figure S7. Confocal images of GSH levels induced with $\mathrm{H}_{2} \mathrm{O}_{2}$ in HT-22 cells with BCy-SeSe (10 $\mu \mathrm{M}$ ). (a)-(f) Images of GSH level in HT-22 cells at points of $0 \mathrm{~min}, 1 \mathrm{~min}, 2 \mathrm{~min}, 3 \mathrm{~min}, 4 \mathrm{~min}$ and 5 min upon pre-incubated with $\mathrm{H}_{2} \mathrm{O}_{2}(500 \mu \mathrm{M}) . \mathrm{H}_{2} \mathrm{O}_{2}$ was incubated at $0-2$ min and $\mathrm{H}_{2} \mathrm{O}_{2}$-free after $2 \mathrm{~min}$. The images in second line were bright-field.

\section{Imaging GSH and co-localization in living HT-22 cells with BCy-SS}

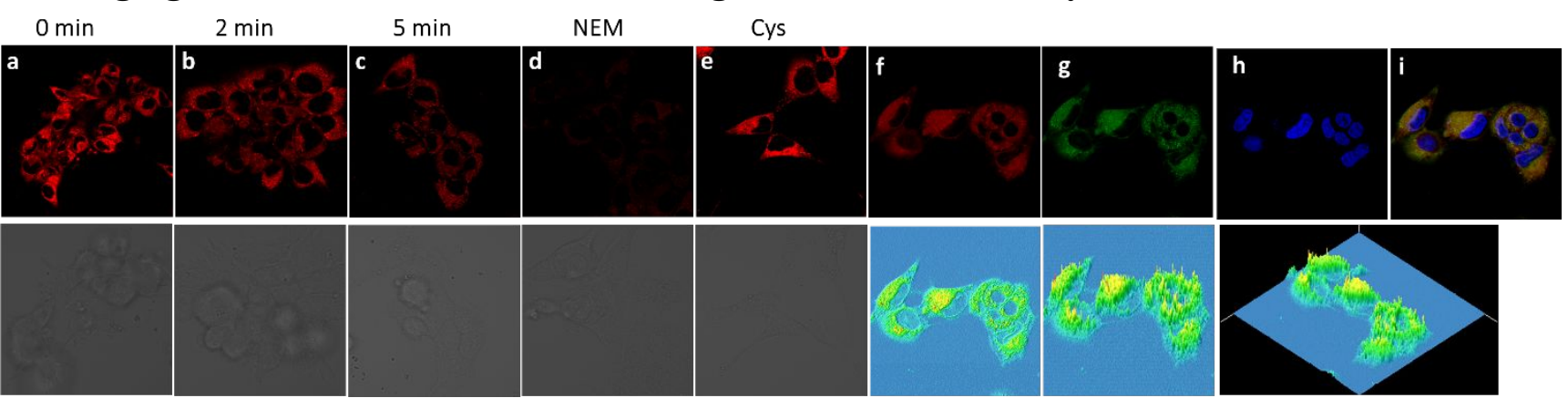

Figure S8. Confocal images of GSH levels induced with $\mathrm{H}_{2} \mathrm{O}_{2}$ in HT-22 cells and mitochondrial multicolor co-localization in HT-22 cells with BCy-SS $(10 \mu \mathrm{M})$. (a)-(c) Images of GSH level in HT-22 cells at points of 0 min, 2 min and 5 min upon pre-incubated with $\mathrm{H}_{2} \mathrm{O}_{2}(500 \mu \mathrm{M}) . \mathrm{H}_{2} \mathrm{O}_{2}$ was incubated at 0-2 $\mathrm{min}$ and $\mathrm{H}_{2} \mathrm{O}_{2}$-free after $2 \mathrm{~min}$. The corresponding images in second line were bright-field. (d) HT-22 cells were washed after the same operation as group (c) and then treated with NEM $(500 \mu \mathrm{M})$ for $20 \mathrm{~min}$. (e) HT-22 cells were washed after the same operation as group (d) and then treated with Cys $(500 \mu \mathrm{M})$ for $20 \mathrm{~min}$. Before imaging, above cells were washed with PBS for three times after respective operation and incubated with BCy-SS $(10 \mu \mathrm{M})$ for 5 min. (f)-(i) Mitochondrial multicolor co-localization in HT-22 cells with BCy-SS (red channel) for 5 min (f), MitoTracker ${ }^{\circledR}$ Green FM (1 $\mu \mathrm{g} / \mathrm{mL}$, green channel) for $15 \mathrm{~min}(\mathrm{~g})$ and Hoechst 33342 for $30 \mathrm{~min}(1$ $\mu \mathrm{g} / \mathrm{mL}$, blue channel) (h). (i) Overlay image of three channels. The images in second line were perspective observation of multicolor co-localization. Red channel: $\lambda_{\mathrm{em}}=700-800 \mathrm{~nm}\left(\lambda_{\mathrm{ex}}=635\right.$ $\mathrm{nm})$. Green channel: $\lambda_{\mathrm{em}}=500-580 \mathrm{~nm}\left(\lambda_{\mathrm{ex}}=488 \mathrm{~nm}\right)$. Bule channel: $\lambda_{\mathrm{em}}=420-480 \mathrm{~nm}\left(\lambda_{\mathrm{ex}}=405\right.$ $\mathrm{nm})$. 
11. Bright-field images of Figure 1 and other images of co-localization

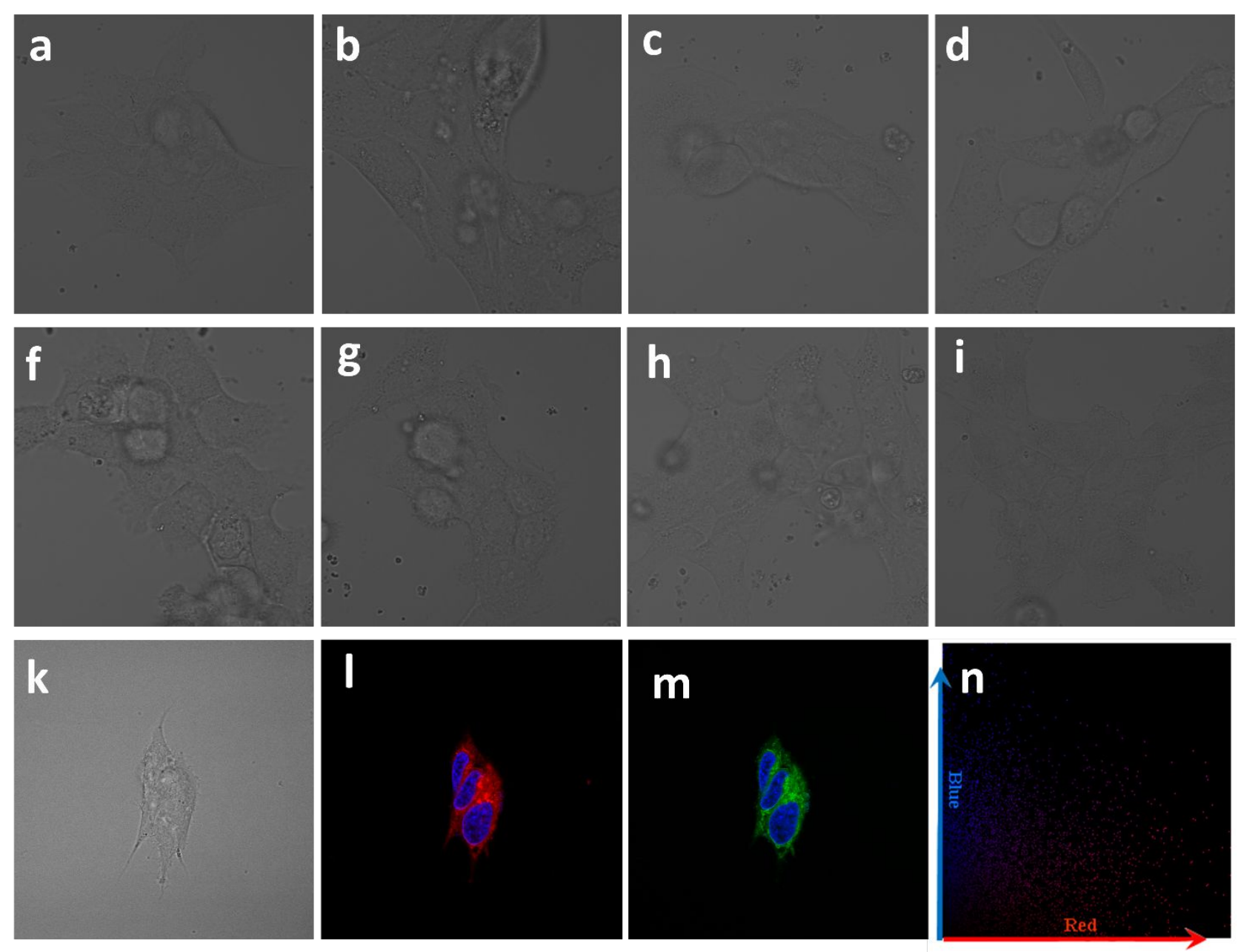

Figure S9. Bright-Field Images of Figure. 1a-1d, Figure.1f-1i and Figure.1k. And overlay images of red and blue channels, green and blue channels, co-localization areas of red and blue channels. 
12. Bright-field images of Figure 2, Figure 3 and Figure 4

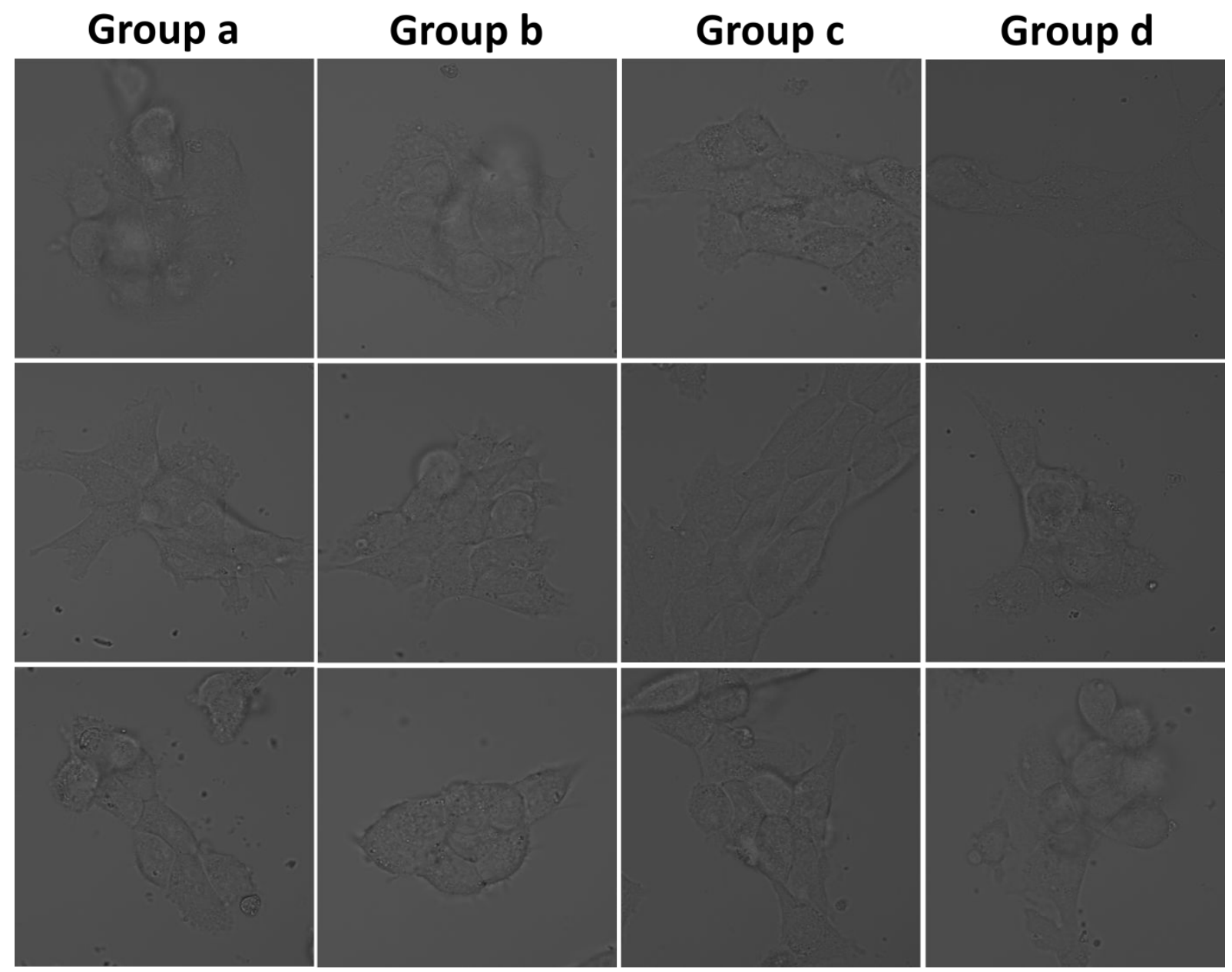

Figure S10. Bright-Field Images of Figure. 2A.

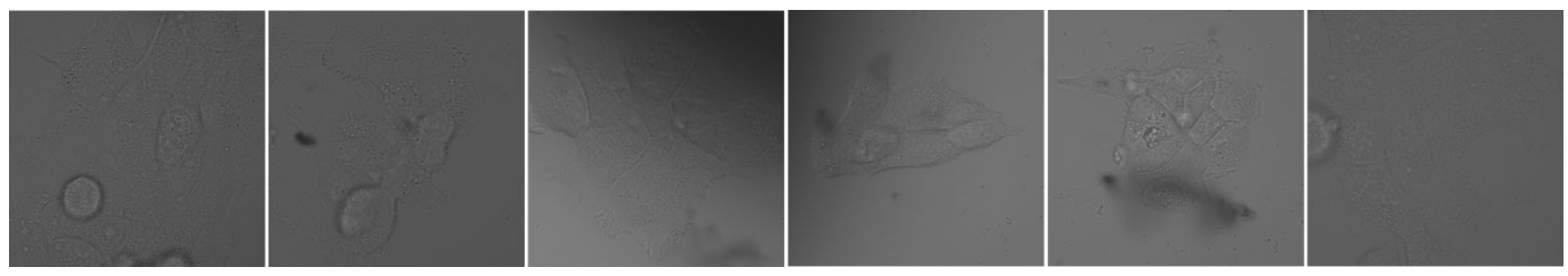

Figure S11. Bright-Field Images of Figure. 3A. 


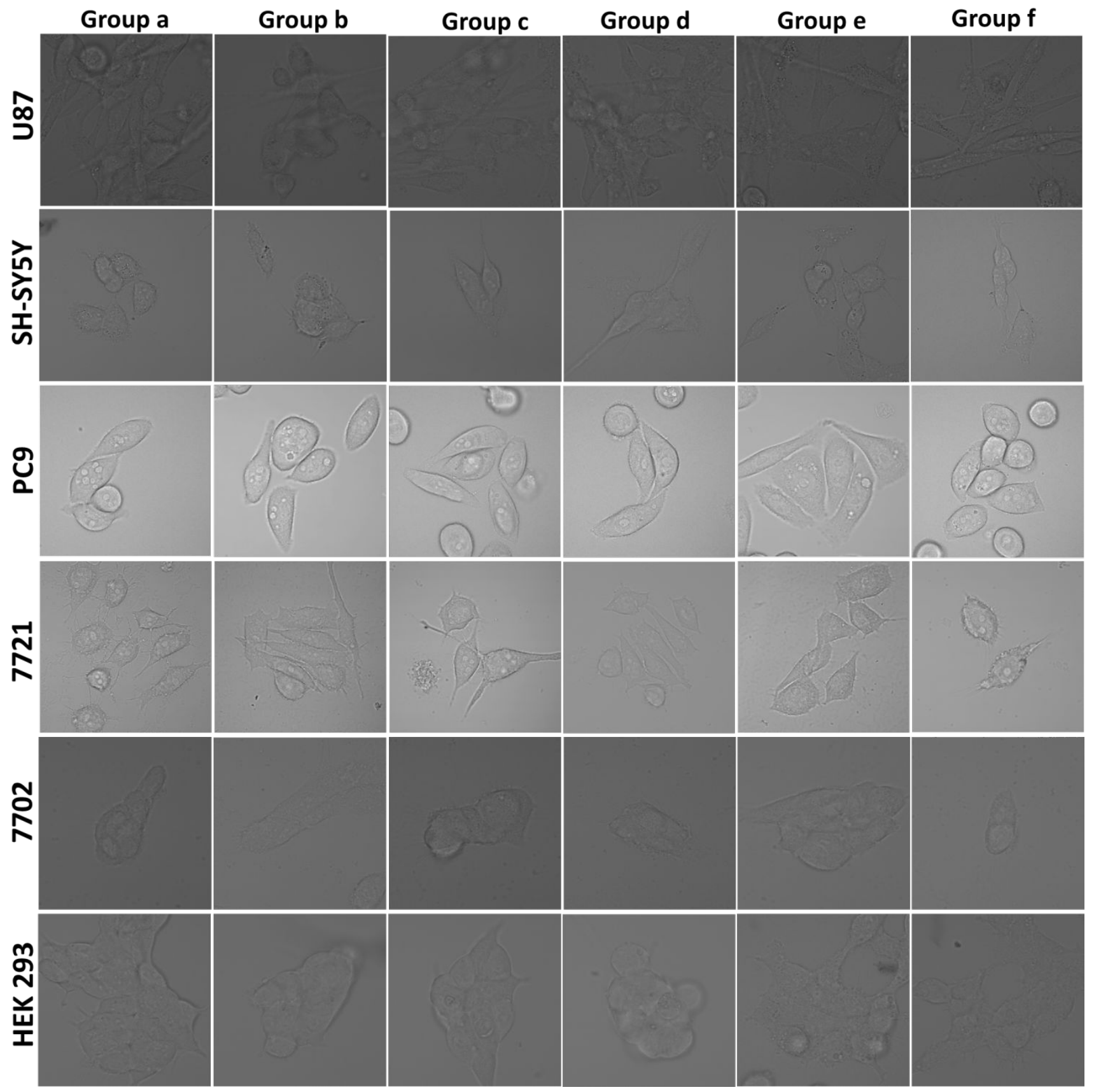

Figure S12. Bright-Field Images of Figure. 4A. 


\section{Representative slides of H\&E and TUNEL staining of lesion brain sections in Figure 6}

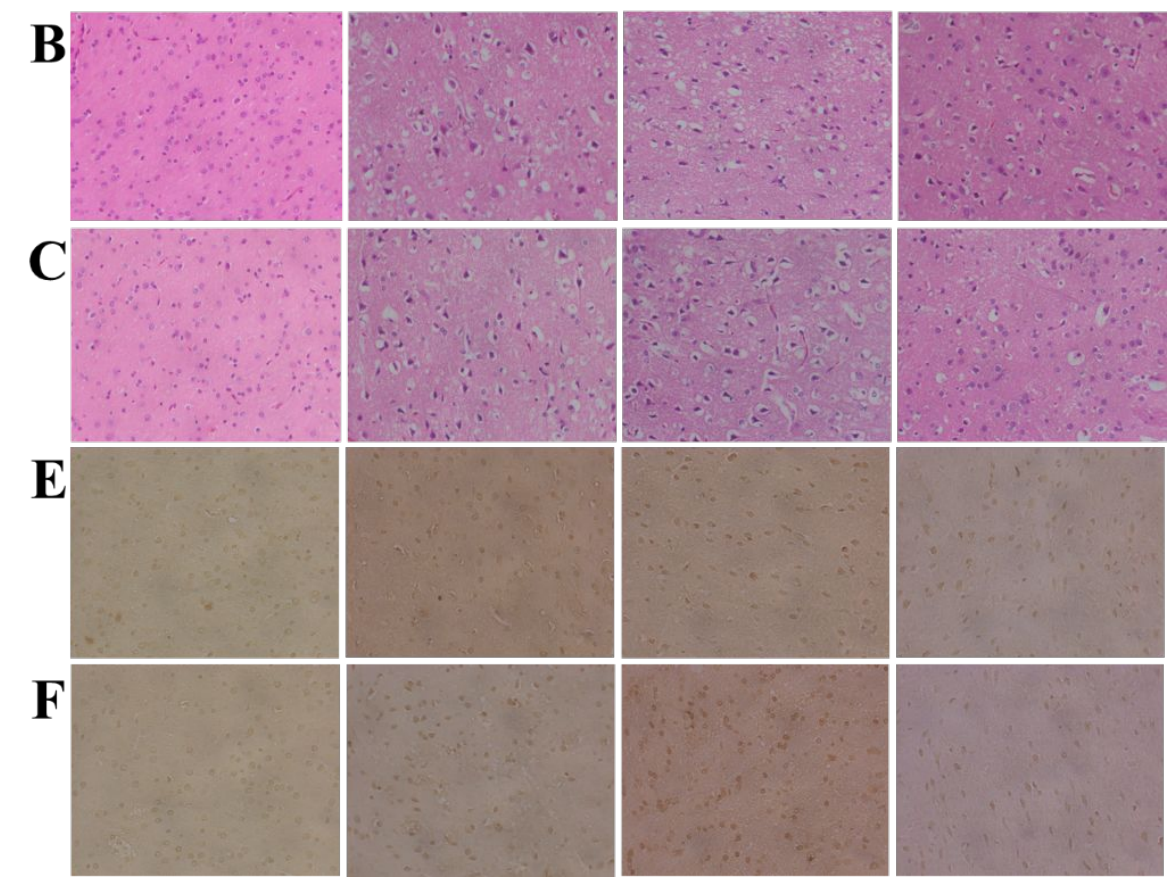

Figure S13. Enlarged figures of H\&E and TUNEL slides in Figure. 6B-6C and 6E-6F.

\section{The purities tests of BCy-SeSe and BCy-SS by HPLC}

To confirm the reaction mechanism of two probes to GSH, the products from these two reactions were characterized by HPLC analysis (figure S14). The probes were respectively diluted to $10 \mu \mathrm{M}$ with $10 \mathrm{mM}$ HEPES (pH 7.4) and then reacted with $5 \mathrm{mM} \mathrm{GSH}$ for $0.5 \mathrm{~min}$ (BCy-SeSe) or 3 $\min (\mathrm{BCy}-\mathrm{SS})$ at $37^{\circ} \mathrm{C}$. The probes, fluorophore and derivatized samples were respectively prepared $10 \mu \mathrm{M}$ and filtered through a $0.22 \mu \mathrm{m}$ membrane for HPLC analysis. Method: $\mathrm{C}_{18}$ column $(5 \mu \mathrm{m}$, $150 \mathrm{~mm} \times 4.6 \mathrm{~mm}$ ), mobile phase was gradient elution $10 \%-90 \% \mathrm{CH}_{3} \mathrm{CN}$ in water for $20 \mathrm{~min}$. The column temperature was $25^{\circ} \mathrm{C}$, and the injection volume was $10 \mu \mathrm{L}$. The flow rate was $1 \mathrm{~mL} / \mathrm{min}$. Under experimental conditions the probes BCy-SeSe and BCy-SS eluted at $5.15 \mathrm{~min}$ and $5.10 \mathrm{~min}$, respectively (figure S14a-b). And the fluorophore BCy-Keto eluted at $14.00 \mathrm{~min}$ (figure S14c). Two peaks in figure S14d were consistent with the peaks of BCy-SeSe and fluorophore, which displayed the two main ingredients in the mixture of $\mathrm{BCy}-\mathrm{SeSe}$ and $\mathrm{GSH}$ when the reactions were not complete. Figure S14e showed the results of the reaction between BCy-SS and GSH.

We described the reaction mechanism of the probes BCy-SeSe and BCy-SS for GSH in the manuscript. This type of response mechanism, cleavage of the diselenide or disulfide bond via selenium-sulfur or sulfur-sulfur exchange reaction and then undergo intramolecular cyclization to release the fluorophore BCy-Keto, was well proved in reported work. ${ }^{1,9,10}$ 

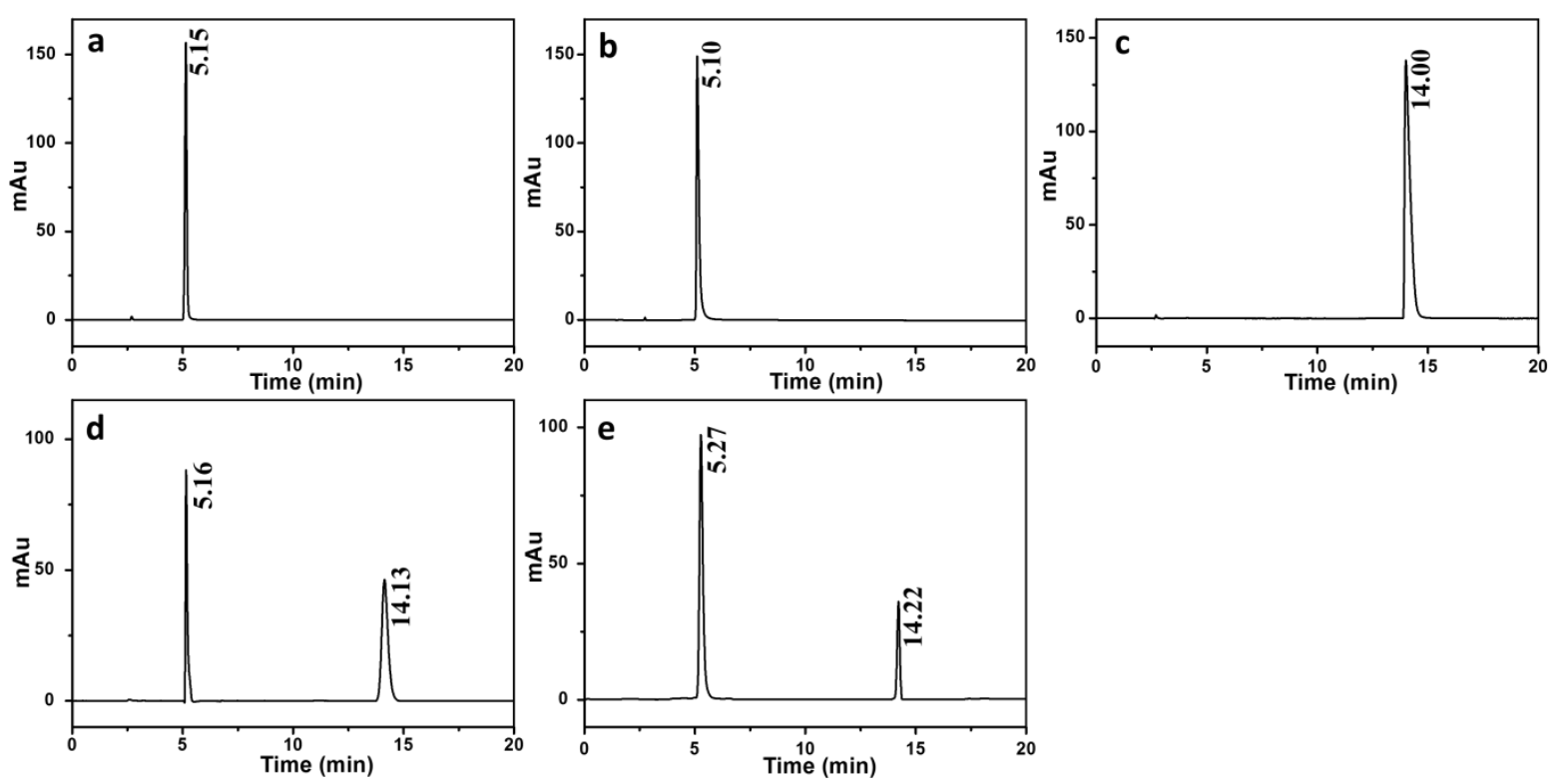

Figure S14. The purities of probes BCy-SeSe (a) and BCy-SS (b) were tested by HPLC. The purity of fluorophore BCy-Keto (c). HPLC test for confirming the product from the reaction between $\mathrm{BCy}-\mathrm{SeSe}$ and GSH for $0.5 \mathrm{~min}(\mathrm{~d})$ or BCy-SS and GSH for 3 min (e) at $37^{\circ}$. The samples $(10 \mu \mathrm{M})$ were respectively injected into the HPLC system equipped with a $\mathrm{C}_{18}$ column $(5 \mu \mathrm{m}, 150 \mathrm{~mm} \times 4.6$ $\mathrm{mm}$ ). Method: mobile phase was gradient elution $10 \%-90 \% \mathrm{CH}_{3} \mathrm{CN}$ in water for 20 min. The detection temperature was $25^{\circ} \mathrm{C}$. The flow rate was $1 \mathrm{~mL} / \mathrm{min}$.

\section{The solubility of the probes}

During living cell imaging, water solubility is a critical parameter for fluorescent probes. ${ }^{11}$ In our initial design of the probe, hydrophilicity and hydrophobicity were taken into account to ensure that the probes could entry into cells and avoid agglomeration and solubility problems. Therefore, the amphiphilic probes were designed.

Furthermore, we introduced the octanol/water partition coefficient ( $\log D$ value) to estimate the solubility of the probes at $\mathrm{pH}=7.4 \cdot{ }^{12-15} \log D$ is defined as:

$$
\log D=\log \left(\sum \mathrm{ai}^{\text {octanol }^{\prime}} / \Sigma \mathrm{ai}^{\mathrm{H} 2 \mathrm{O}}\right) \text {, }
$$

where $a_{i}{ }^{\text {octanol }}$ is the concentration of the $i$ th microspecies in the octanol phase, and $a_{i}{ }^{\mathrm{H} 2 \mathrm{O}}$ is the concentration of the $i$ th microspecies in the aqueous phase at $\mathrm{pH}=7.4 .{ }^{14}$

The $\log D$ of BCy-SeSe and BCy-SS at $\mathrm{pH}=7.4$ were 3.56 and 3.37 , respectively. These data demonstrated that our probes own suitable hydrophilic and lipophilic property under the experiment conditions to ensure application in cells and in vivo without aggregate.

In order to comprehensively evaluate solubility property of our probes, we performed the dose-dependent titration experiment of fluorophore. Solutions of fluorophore BCy-Keto with different concentration were prepared in $10 \mathrm{mM}$ HEPES (containing 20\% fetal bovine serum, v/v, $\mathrm{pH}$ 7.4). The mixture was stirred for $30 \mathrm{~min}$ at $37{ }^{\circ} \mathrm{C}$. Dose-dependent fluorescence titration experiment of fluorophore BCy-Keto $(2-30 \mu \mathrm{M})$ in simulated physiological conditions was shown in Figure S15. BCy-Keto not only did not aggregate when the concentration was less than $18 \mu \mathrm{M}$, but also had a good range of fluorescence intensity. Therefore, the experimental concentration of probes $(10 \mu \mathrm{M})$ would not affect the imaging effects. And even the fluorescence intensity reached the 
plateau at more than $20 \mu \mathrm{M}$, there would be no agglomeration within a certain range of concentration.

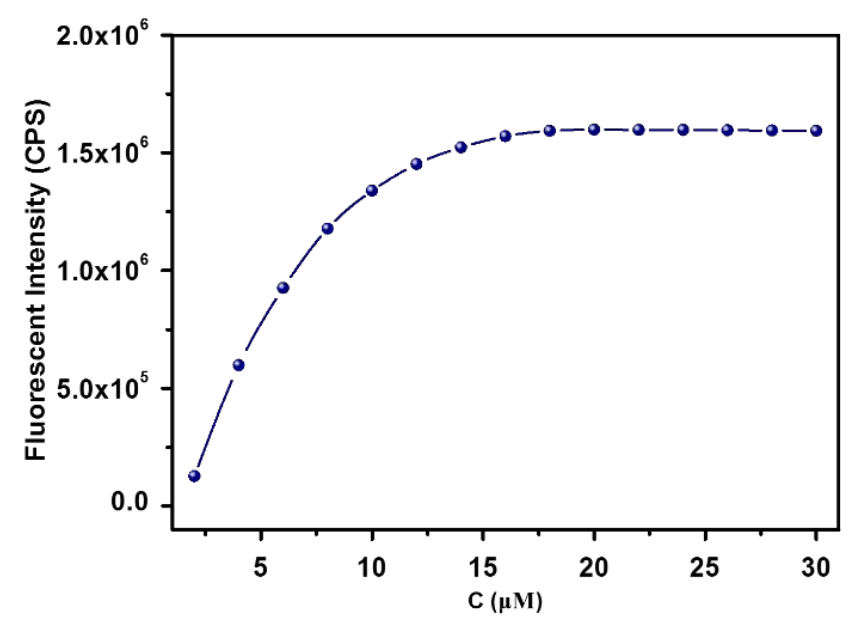

Figure S15. Dose-dependent fluorescence titration experiment of fluorophore BCy-Keto $(2-30 \mu \mathrm{M})$ in the simulated physiological conditions (10\% fetal bovine serum (FBS) in 10 mM HEPES, pH 7.4). $\lambda_{\mathrm{ex}}=654 \mathrm{~nm}, \lambda_{\mathrm{em}}=728 \mathrm{~nm}$. The data were shown as mean $( \pm$ s.d. $)(n=7)$.

\section{6. ${ }^{1} \mathrm{H}$ NMR, ${ }^{13} \mathrm{C}$ NMR and MS}

\section{${ }^{1} \mathrm{H}-\mathrm{NMR}$ for BCy-Keto}
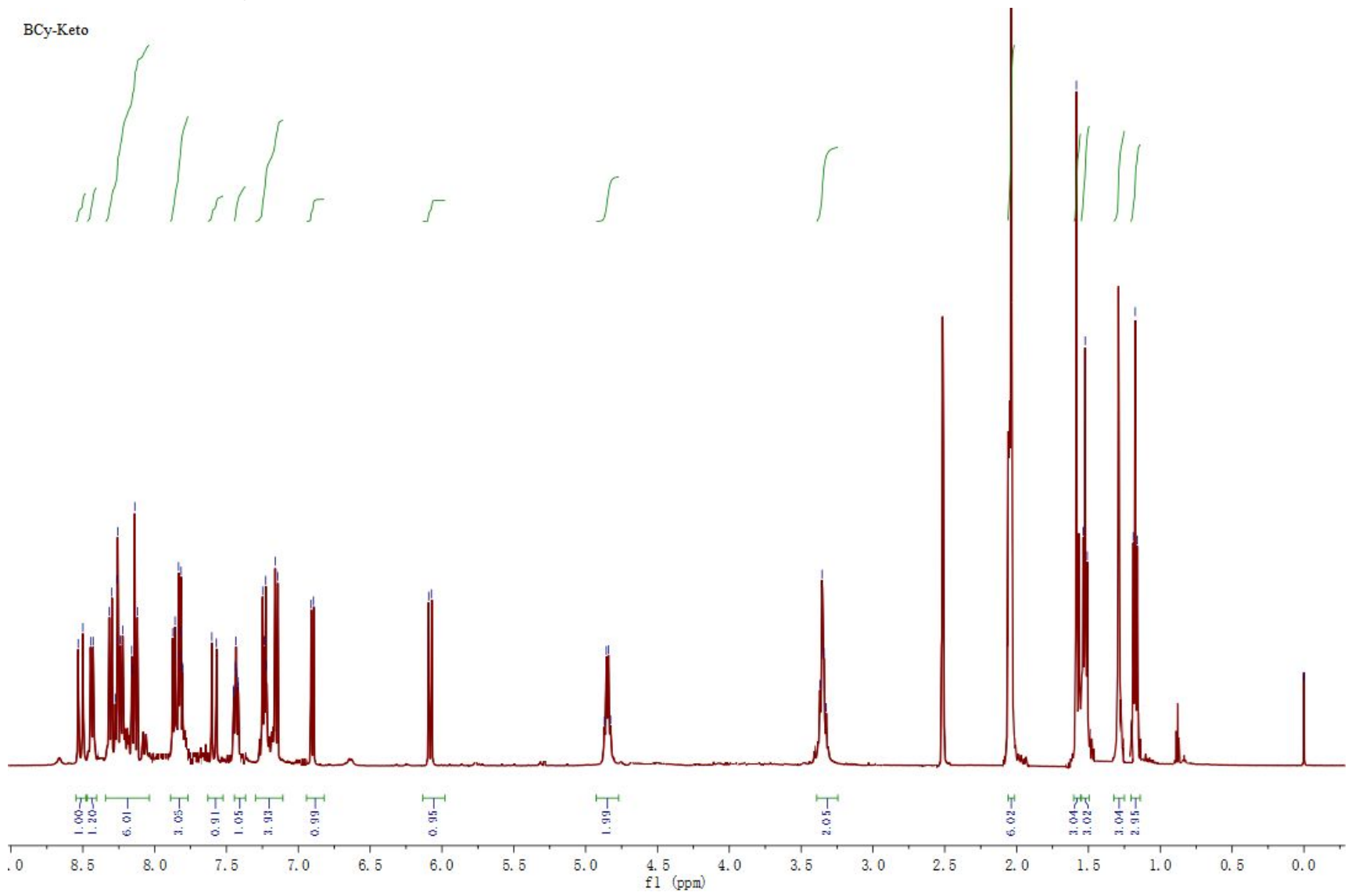

${ }^{13} \mathrm{C}-\mathrm{NMR}$ for BCy-Keto 


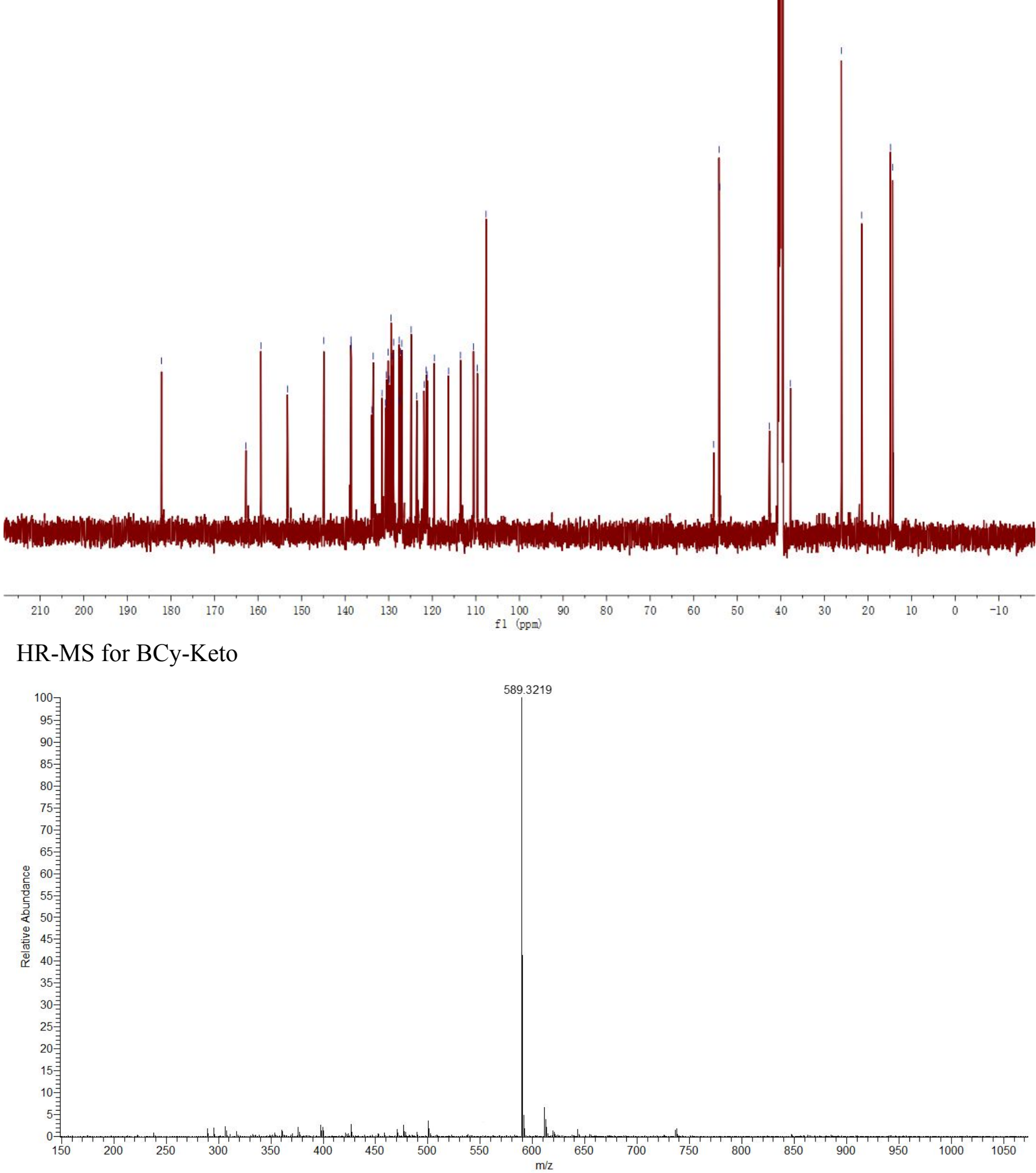

${ }^{1} \mathrm{H}-\mathrm{NMR}$ for BCy-SeSe 
BCy-DiSe
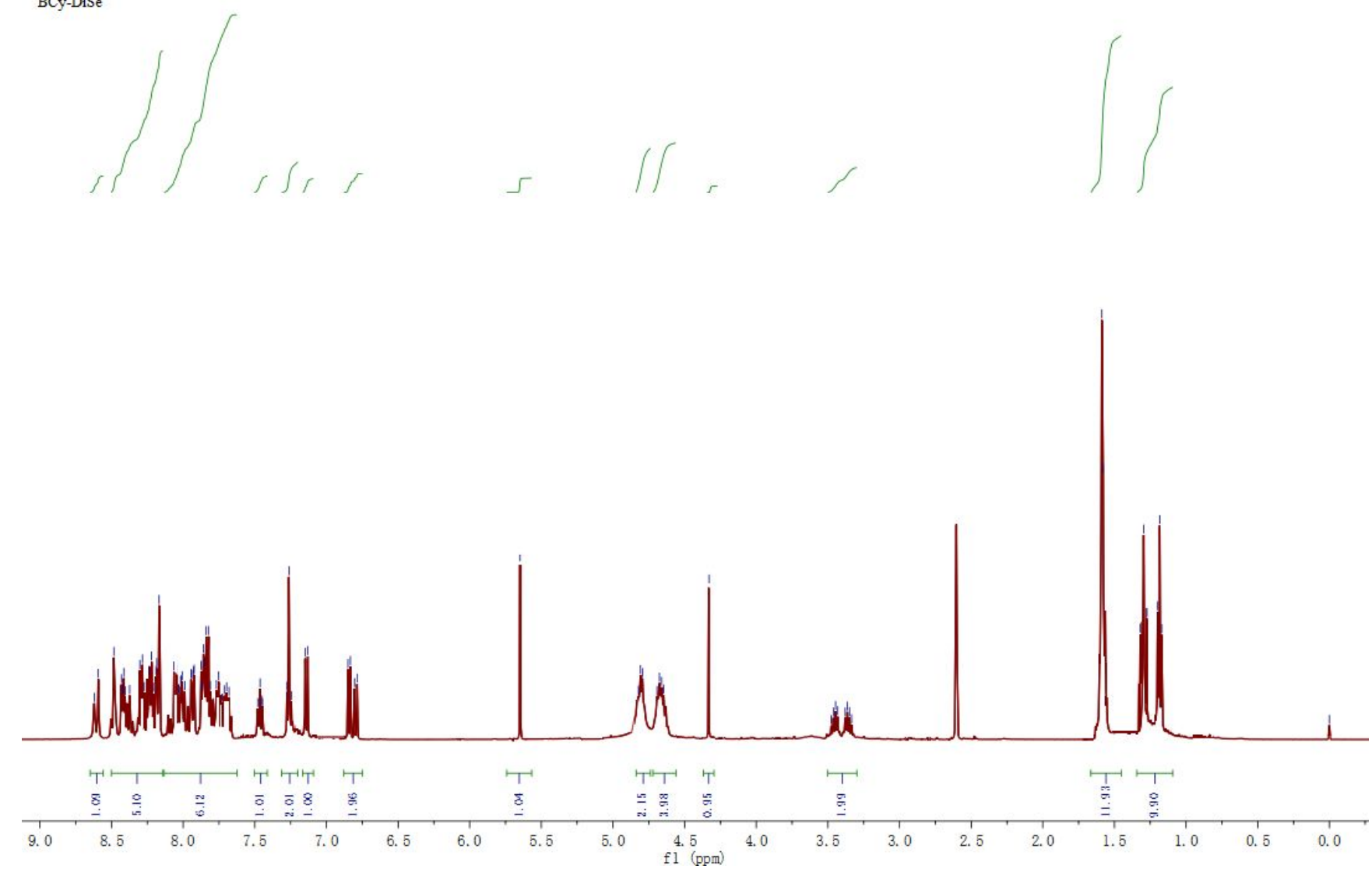

${ }^{13} \mathrm{C}-\mathrm{NMR}$ for BCy-SeSe

BCy-DiSe

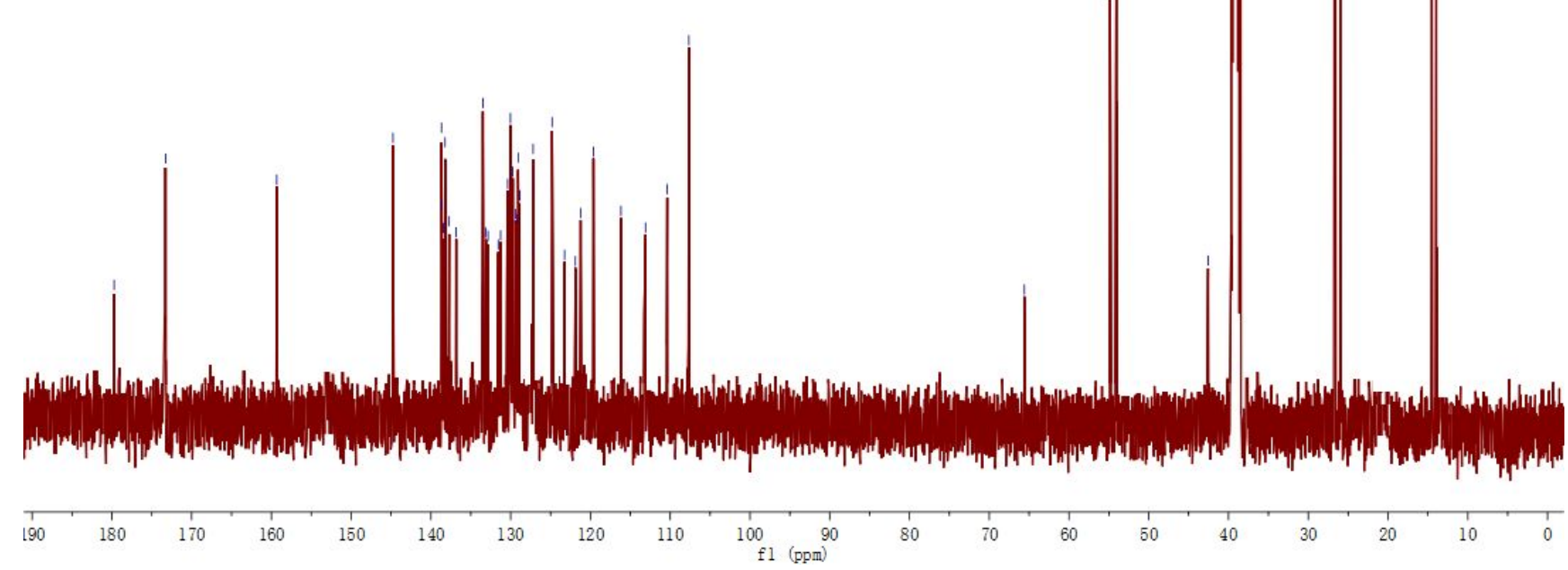

HR-MS for BCy-SeSe 


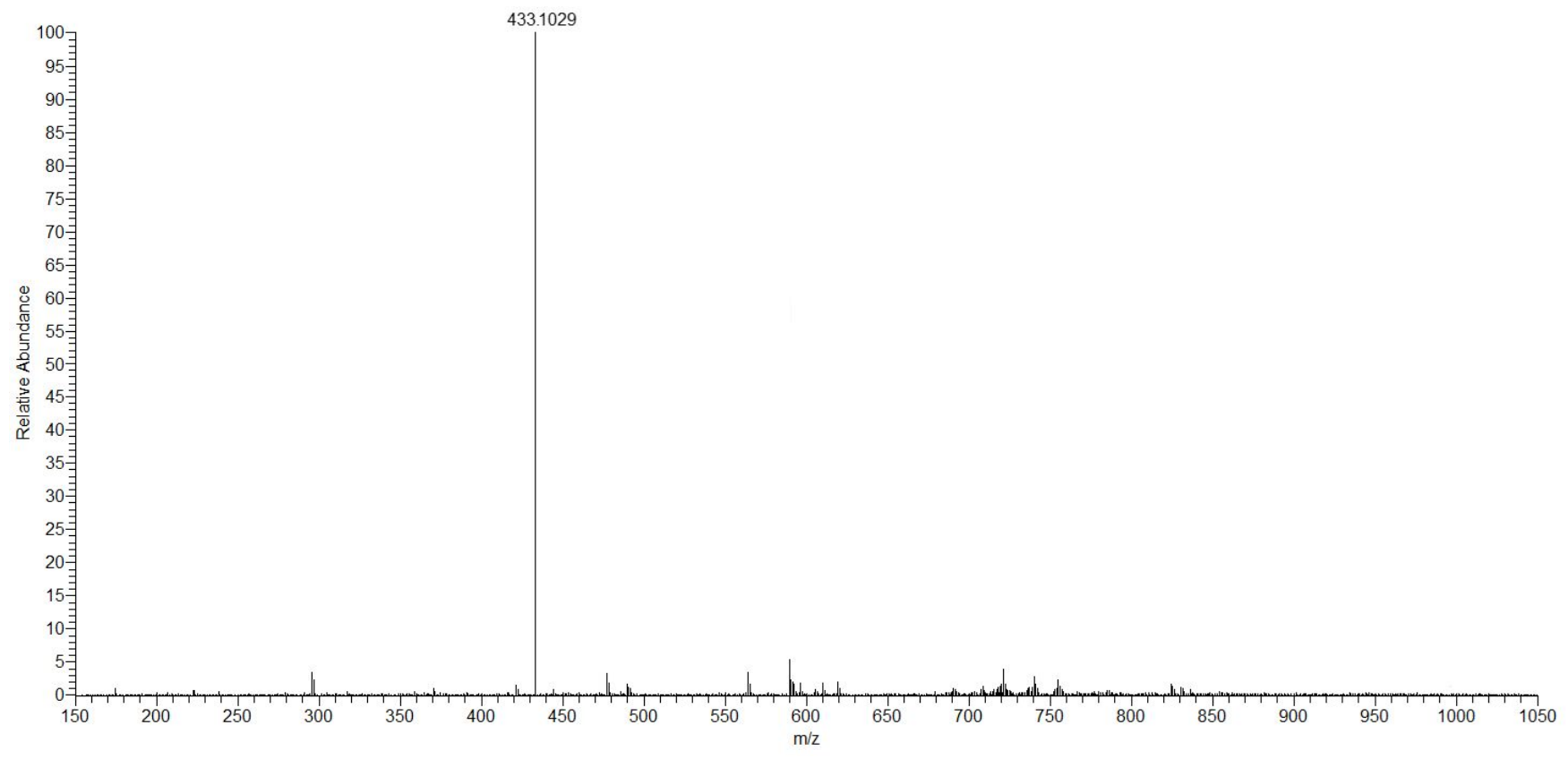

${ }^{1} \mathrm{H}-\mathrm{NMR}$ for BCy-SS

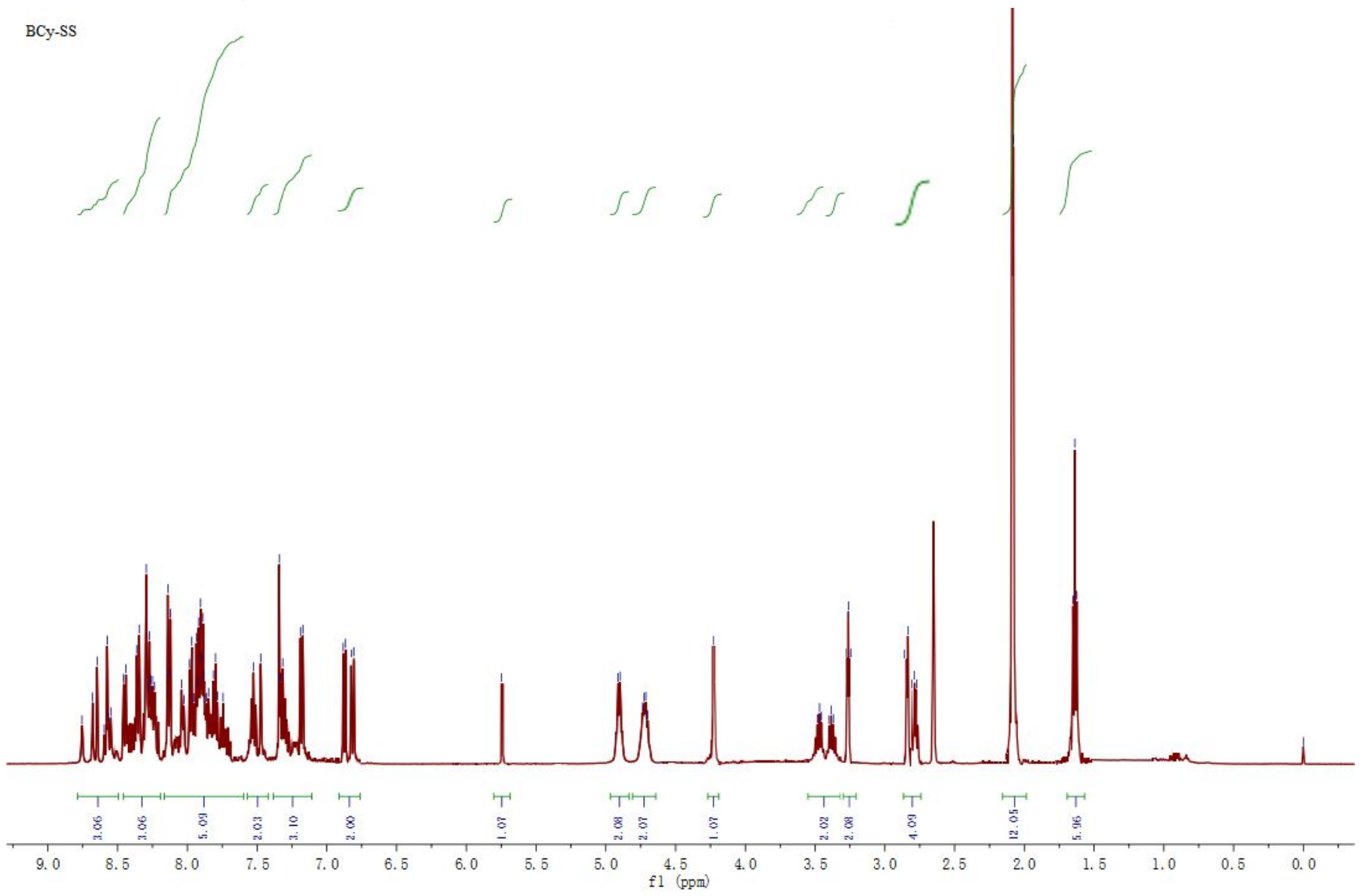

${ }^{13} \mathrm{C}-\mathrm{NMR}$ for BCy-SS 


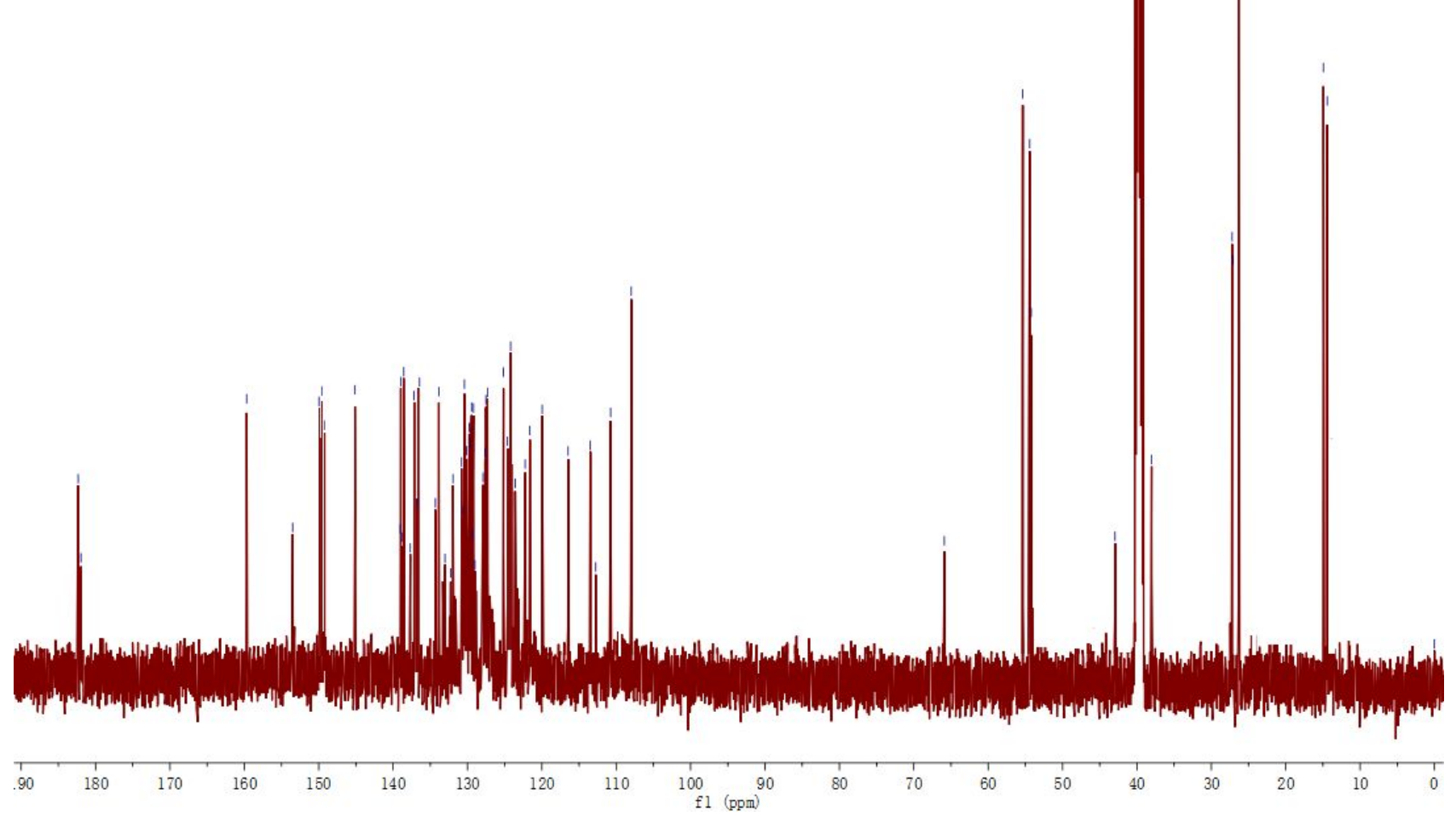

HR-MS for BCy-SS

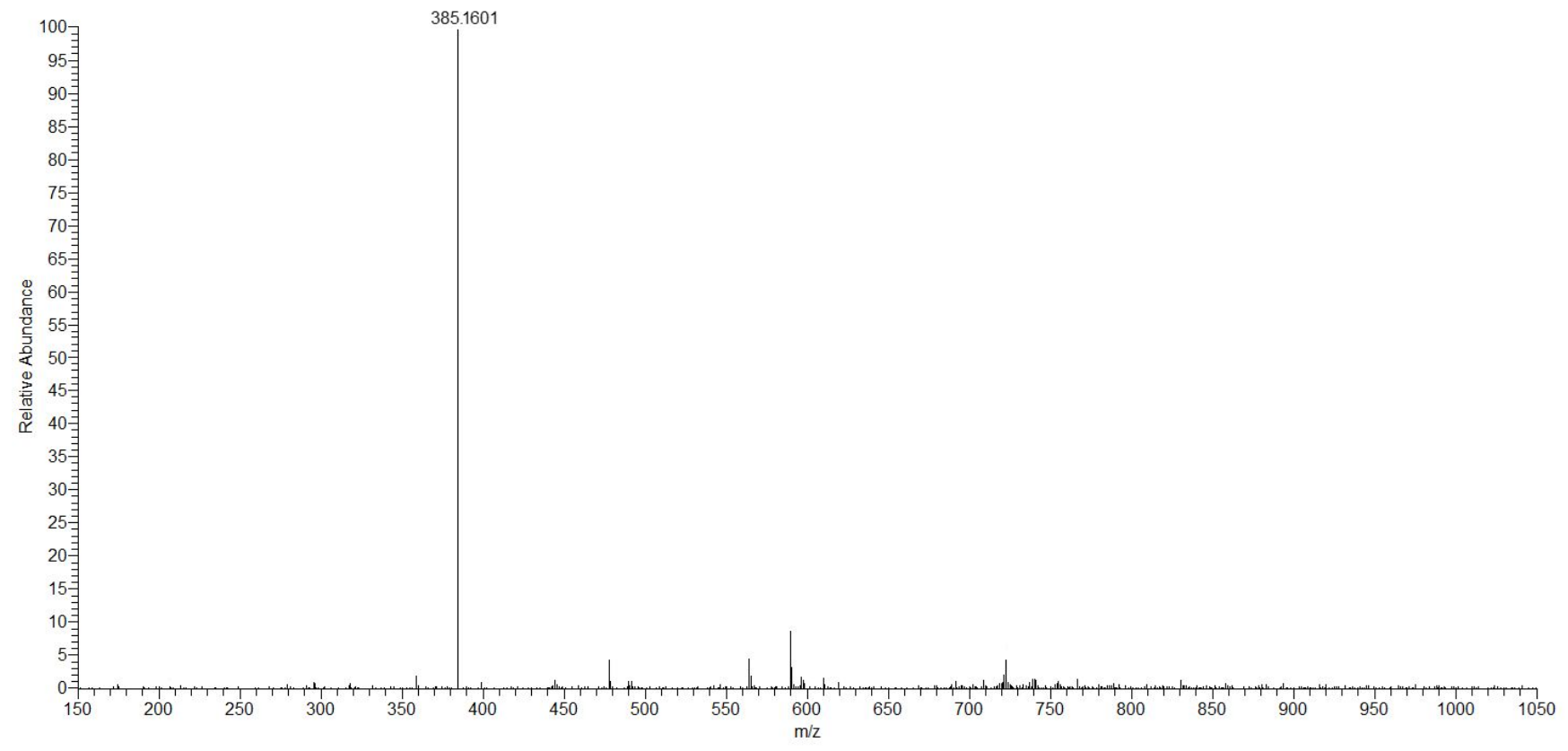




\section{Reference}

[1] Han, X.; Yu, F.; Song, X.; Chen, L., Chem Sci, 2016, 7, 5098-5107.

[2] Gao, M.; Wang, R.; Yu, F.; Chen, L., Biomaterials, 2018, 160, 1-14.

[3] Li, Q.; Li, W.; Cui, S.; Sun, Q.; Si, H.; Tang, B., Biosens Bioelectron, 2019, 129, 132-138.

[4] Mizui, T.; Kinouchi, H.; Chan, P. H., Am J Physiol-heart C, 1992, 262, H313-H317.

[5] Yu, F.; Gao, M.; Li, M.; Chen, L., Biomaterials, 2015, 63, 93-101.

[6] Karton-Lifshin, N.; Segal, E.; Omer, L.; Portnoy, M.; Satchi-Fainaro, R.; Shabat, D., J Am Chem Soc, 2011, 133, 10960-10965.

[7] Liu, X.; Qiao, Q.; Tian, W.; Liu, W.; Chen, J.; Lang, M. J.; Xu, Z., J Am Chem Soc, 2016, 138, 6960-6963.

[8] Han, X.; Wang, R.; Song, X.; Yu, F.; Lv, C.; Chen, L., Biomaterials, 2018, 156, 134-146.

[9] Huang, C.; Jia, T.; Tang, M.; Yin, Q.; Zhu, W.; Zhang, C.; Qian, X. J Am Chem Soc. 2014, 40, 14237-14244.

[10] Han, X.; Song, X.; Yu, F.; Chen, L. Adv. Funct. Mater. 2017, 27, 1700769.

[11] Gao, P.; Pan, W.; Li, N.; Tang, B., Chem Sci, 2019, 10, 6035-6071.

[12] Hyun, H.; Park, M. H.; Owens, E. A.; Wada, H.; Henary, M.; Handgraaf, H. J.; Choi, H. S., Nat med, 2015, 21, 192-197.

[13] Tan, X.; Luo, S.; Long, L.; Wang, Y.; Wang, D.; Fang, S.; Shi, C., Adv mater, 2017, 29, 1704196.

[14] Bhat, K. L.; Garg, A.; Bock, C. W., Dyes pigments, 2002, 52, 145-159.

[15] Kohl, C.; Weil, T.; Qu, J.; Müllen, K., Chem-Eur J, 2004, 10, 5297-5310. 